Tarih Kültür ve Sanat Araştırmaları Dergisi

Revue des Recherches en Histoire Culture et Art

مجلة البحوث التاريخية و الثقافية و الفنية
Vol. 7, No. 2, June 2018

Copyright (C) Karabuk University

http://kutaksam.karabuk.edu.tr

\title{
DOI: 10.7596/taksad.v7i2.1425
}

Citation: Zavalsız, Y., \& Şahin, E. (2018). Ateist ve Deistlerin Din Algısı: Üniversite Öğrencileri Üzerine Psiko-Sosyolojik Bir Araştırma. Journal of History Culture and Art Research, 7(2), 567599. doi:http://dx.doi.org/10.7596/taksad.v7i2.1425

\section{Ateist ve Deistlerin Din Algısı: Üniversite Öğrencileri Üzerine Psiko-Sosyolojik Bir Araştırma}

\section{Approach of Atheists and Deists to Religion: A Psycho-Sociological Research on University Students}

\author{
Y. Sinan Zavalsız ${ }^{1}$, Ensar Şahin ${ }^{2}$
}

\begin{abstract}
This study deals with changing views and attitudes of individuals towards creator and religion. Apart from this, we analyzed the reasons behind the change of opinions.

In this paper, we also investigated in a psychosocial approach what lies in the background of that through which atheists and deists adopted this understanding. After we briefly explained the terms "atheism" and "deism" we inquired about the family relations of respondents beginning from their childhood and puberty ages. We asked the respondents whether they are informed by families and the frequency of their practising the duties of past religious affiliates which is followed by sceptical manner about the religion adhered questioning if they experienced any traumatic event and examined the circumstances that motivated them to be atheists or deists. We also sought to determine similarities and differences between atheists and deists in terms of the way of thinking.

This research has been prepared within the frame of the interviews carried out with 25 volunteers, 15 of whom were atheists and 10 deists. Some of the interviews were recorded after the consent of the interviewees had been obtained. As per the right of privacy and the request of the subjects, their universities, identity and personal information have been kept confidential. Nevertheless, they have been given nicknames to be used exclusively in this research.
\end{abstract}

Keywords: Atheism, Deism, Perception of God, Perception of Religion, Change of Belief, Conversion.

\footnotetext{
${ }^{1}$ Assist. Prof. Dr., Karabuk University, Department of Sociology. E-mail: sinanzavalsiz@hotmail.com

${ }^{2}$ Karabük Üniversitesi Lisans Mezunu. E-mail: ensarsahin9461@gmail.com
} 
Araştırmamız, Ateist ve Deistlerin Din Algısı: Üniversite Öğrencileri Üzerine Psiko-Sosyolojik Bir Araştırma başlığı altında, bireylerin, yaratıcı ve din konusunda değişen düşüncelerini ele almaktadır. Düşünce değişikliğinin arka planında hangi kodların bulunduğu ayrıca irdelenmeye çalışılımıstır.

Bu çalışmada ateist ve deistlerin, arka planda ateizmi ve deizmi benimsemesine yol açan sebeplerin neler olduğu psiko-sosyal bir bakış açısıyla incelenecektir. Ateizm ve deizmin ne olduğu kısaca izah edildikten sonra deneklerin çocukluk ve ergenlik döneminden başlanarak aile ilişkileri ele alınmışır. Dinî konularda ailesi tarafından bilgilendirilme durumu, toplumla ilişkileri, daha önce mensup olduğu dinin ibadetlerini yerine getirip getirmeme sıklığı sorulmuştur. Sonrasında mensup olunan dine dair taşınan şüpheler, hayatlarını etkileyen travmatik bir olay yaşayıp yaşamadıkları, onları ateist veya deist olmaya iten faktörler irdelenmiştir. Ateist ve deistlerin birbirinden ayrıldığı ve benzer düşündüğü konular ortaya çıkartılmaya çalışıııştır.

Araştırma, 15'i ateist, 10'u deist, toplam 25 gönüllü öğrenci ile gerçekleştirilen mülakatlar çerçevesinde ortaya çıkmıştır. Mülakatlarda, isteğe bağlı olarak ses kaydı alınmıştır. Özel hayatın gizliliği ilkesince ve deneklerin talepleri doğrultusunda, üniversiteleri, kimlik bilgileri ve isimleri gizli tutulmuş, yalnız bu çalışmada kullanılmak üzere kendilerine takma isim verilmiştir.

Anahtar Kelimeler: Ateizm, Deizm, Tanrı Algısı, Din Algısı, İnanç Değişikliği.

\section{Giriş}

Din olgusu insanlık tarihi boyunca toplumların hayatında önemli bir unsurdur. Bilinen tüm toplumlarda karşımıza çıkan bu olgu, bireyin yaşadığı çevreyi nasıı algılayacağını ve o çevreye nasıl tepki vereceğini belirleyerek toplumsal yaşantının önemli bir parçası olmuştur. ${ }^{3}$ Bilim ve teknolojinin gelişmediği dönemlerde insan, cevabını bulamadığı soruları din vasıtasıyla cevaplamıştır. Modern dönemde bilimin ilerlemesi, teknolojinin geniş alanları etkilemesi önemli değişimlere sebep olmuş, bilimsel yöntemlerle elde edilen bilgi hakikatin ölçüsü haline gelmiştir. ${ }^{4}$ Bilimin önem kazanması, giderek daha kapsamlı bir şekilde düşüncelerimizi ve içinde yaşadığımız kurumları etkilemesi, dinin söylemlerine muhalefet etmesi, din ile bilim arasındaki çatışmaları kaçınılmaz kıımıştır. ${ }^{5}$

Dinin söylemlerine karşı en büyük muhalefet kuşkusuz, bilimin, teknolojinin, sanatın ve edebiyatın somut değişimler gösterdiği Batı dünyasında meydana gelmiştir. Rönesans ve Reform hareketleri, Aydınlanma düşüncesi, meydana gelen değişimin en önemli sebebi olmuştur. Aydınlanma düşüncesi yaşamın her alanında etkisini göstermiş, insanı varoluşuyla ve evrenle ilgili aklını kullanmaya ve eleştirel bir tavır takınmaya yöneltmiştir. Din, vahiy, Tanrı gibi olgular insan aklıyla paralellik gösterdiği sürece meşru sayılmıştır. Aydınlanma düşüncesinin ardından 19. yüzyılda pozitivizmin ortaya çıkmasıyla dine ve Tanrı́ya yöneltilen eleştiriler zirveye ulaşmıştır. ${ }^{6}$

Deney ve gözleme dayanmayan hiçbir bilgiyi kabul etmeyen pozitivizm, Tanrı'yı, dini ve metafizik olguları, insanlığın gelişmesini engelleyen bilim öncesi düşünce tarzları olarak nitelemiştir. ${ }^{7}$ Pozitif çağda insan

\footnotetext{
${ }^{3}$ Antonhy Giddens, Sosyoloji, Yayıma Hazırlayan: Cemal Güzel, ìstanbul 2008, ss. 579-580.

${ }^{4}$ Ali Bayer, Sosyolojik Perspektiften Sekülerleşme ve Din ilişkisine Yeniden Bakış, Kahramanmaraş Sütçü İmam Üniversitesi, Sosyal Bilimler Enstitüsü, (Yayımlanmamış Yüksek Lisans Tezi) Kahramanmaraş 2006, s. 1.

${ }^{5}$ Bertrand Russel, Bilim ve Din, Varlık Dergisi, Sayı: 780, Eylül 1972.

${ }^{6}$ Ergin Ögcem, Ateizmden Deizme Anthony Flew, Marmara Üniversitesi, Sosyal Bilimler Enstitüsü, (Yayımlanmamış Doktora Tezi), ìstanbul 2013, s. i.

${ }^{7}$ Giddens, s. 707.
} 
ulaşamayacağı gerçekleri (Tanrı, metafizik olgular) bir kenara bırakıp, deney ve gözlem yoluyla ulaşabileceği somut varlıkları incelemeye yönelecektir. ${ }^{8}$ Dinin insanlar üzerindeki etkisi eski önemini kaybetmiş, bilimsel araştırmalar sonucu elde edilen verilerin ehemmiyeti artmıştır. Dinden uzaklaşan insan, zamanla Tanrı ile insan arasındaki ilişkiyi koparan deizme, hatta Tanrı inancını tamamen reddeden ateizme yönelmiştir.

\section{Ateizm ve Tarihçesi}

Ateizm terimi, Yunancada olumsuzluk bildiren "a" önekiyle, Tanrı anlamına gelen "Theos"un birleşiminden oluşan ve Tanrı'nın ya da tanrıların var olmadığı düşüncesine inanan felsefi bir akımdır. ${ }^{9}$

Ateizm kavramının tanımlanabilmesi, teizmin anlaşılmasına bağlıdır. Zira ateizm, bir anlamda teizme tepki olarak ortaya çıkmıştır. Dünya üzerinde farklı teistik inanışları ve yorumlamaları görmek mümkündür. Semavî dinlerin tamamı teizm inanışııı benimsemiş olmasına rağmen kendi inançlarını ön plana çıkartıp diğerlerinin teizm yorumunu reddetmiştir. Hıristiyanların teslis inancı ve Yahudilerin kendilerine has millî Tanrı anlayışı bu duruma örnek gösterilebilir. Dolayısıyla farklı teistik yorumlamalar olduğu gibi, farklı ateist anlayışların olması da doğaldır. Teizmi, Tanrı'nın varlığına inanmak ve kabul etmek olarak ifade edersek, ateizmi de bir Tanrı'nın varlığını reddetmek ve bu doğrultudaki bir inanca sahip olmamak şeklinde nitelemek doğru olacaktır. ${ }^{10}$

Türkçede ateizm kavramını tam olarak karşılayan bir kelime olmamasına rağmen "tanrı tanımaz" terimi yaygın olarak kullanılmaktadır. ${ }^{11}$ Ateizm kavramının genel olarak "Tanrı inancına sahip olmayan" şeklinde yapılan tanımının dışında ayrıntılı olarak incelenmesi ve değerlendirilmesi gerekir. Genel ateizm tanımının dışında bazı ateistlere göre ateizm; Tanrı'yı reddetmekten ziyade, "zihinde Tanrı fikrine sahip olmamak" demektir. İnsan doğuştan Tanrı düşüncesine sahip olmadığı için inkâr edecek bir şeyi de bulunmamaktadır. Bu görüşe göre ateist; Tanrı́nın varlığını inkâr etmemeli, "Tanrı yoktur." demeye intiyaç duymamalıdır. Çünkü zaten Tanrı́nın varlığı ispat edilememiştir. Hiçbir şekilde Tanrı düşüncesine sahip olmayan ve salt ateizmi benimseyip, temellendirmeye çalışan bu düşünceye "mutlak ateizm" denilmiş, bu görüşü benimseyenler ise mutlak ateist olarak isimlendirilmiştir. ${ }^{12}$

Bir başka ateizm anlayışı ise "teorik ateizm”dir. Bu görüş basit olarak Tanrı'nın varlığını reddetmek olarak tanımlanmıştır. Fakat Tanrı́nın varlığını reddetmenin yanında birtakım deliller ortaya koyarak, teizm inancıyla ilgili iddiaları çürütüp eleştirme yoluna gitmişlerdir. Teorik ateistlerin birtakım tezler ortaya koyması, teistlerin, ateizmi tepkisel bir düşünce olarak görmelerinden kaynaklanmaktadır. Çünkü teistlere göre Tanrı zaten vardır, reddedilmesi mümkün değildir. Bu açıdan ateistler gerekçesiz olarak Tanrı́nın varlığını reddetmeleri durumunda teistik açıdan dogmatik duruma düşmüş olacaklardır. ${ }^{13}$

Tanrı'yı yaşama sokmamak şeklinde tanımlanan ateizm anlayışı ise "pratik ateizm"dir. Bu düşüncedekiler Tanrı yokmuş gibi yaşamlarını sürdürür. Tanrı'yı bilinçli bir şekilde reddetmek yahut reddetmemek onlar için pek bir önem arz etmez. Kendilerini açıkça ateist diye tanımlamaları, teorik olarak ateist olmaları da gerekmemektedir. ${ }^{14}$

\footnotetext{
${ }^{8}$ Abdurrahman Kurt, Din Sosyolojisi, İstanbul 2015, s. 75.

${ }^{9}$ Ahmet Cevizci, Felsefe Sözlüğü, İstanbul 1999, s. 82.

${ }^{10}$ Aydın Topaloğlu, Teizm ya da Ateizm: Tanrıtanımazlığın Felsefi Boyutları, İstanbul 2001, s. 13.

${ }^{11}$ Necip Taylan, Düşünce Tarihinde Tanrı Sorunu, İstanbul 2000, s. 156.

${ }^{12}$ Topaloğlu, s. 16.

13 İbrahim Coşkun, Ateizm ve İslam: Kelami Açıdan Modern Çağ Ateizminin Eleştirisi, Ankara 2014, s. 23; Topaloğlu, s. 17.

${ }^{14}$ Topaloğlu, s. 18.
} 
Pratik ateistler, aktif ve pasif ateistler olmak üzere ikiye ayrılır. Pasif ateistler kendi hallerinde, Tanrı'yla ve teizm inancını benimseyen bireylerle polemiğe girmeden yaşarken; aktif ateistler zihinlerinde Tanrı inancını reddetmekle birlikte çevrelerindeki dindarlara, Tanrı́yla ilgili fikir ve davranışlara savaş açan kimselerdir. Dindarlarla mücadele eden bu ateistler, insanları dinsizleştirmeyi amaç edinmiş, dinsiz bir toplum hayali kurmuşlardır. S. Freud, K. Marx, F. Nietzsche gibi ünlü düşünürler bu görüşün felsefe alanındaki temsilcileridir. ${ }^{15}$

Diğer bir ateizm görüşü ise Tanrı'nın varlığı veya yokluğu hakkında fikir yürütmenin, tartışmaya girmenin, anlamsız bir iş olduğunu söyleyen “ilgisizlerin ateizmi”dir. Bu anlayış Tanrı'nın varlığına veya yokluğuna ilgisiz kalmış, bu konular için zaman harcanmaması, var olanla yetinilmesi gerektiğini ileri sürmüştür. Ayrıca kendilerini ateist olarak nitelemekten de kaçınmışlardır. Fakat teist olduklarını söylemek de güçtür. Tanrı'nın varlığıyla ilgilenmemek ve anlamsız bir iş olarak görmek bir nevi onu reddetmek gibidir.

Yeniçağ'da Rönesans ile birlikte, doğa bilimlerinin yanısıra dinî bilgilerin de akılla açıklanabileceği düşüncesi ortaya çıkmıştır. Aydınlanma Dönemi ve sonrasında pozitivizm akımıyla metafizik öğretilere karşı savaş açılmıştır. Akıl ve bilim her şeyin ölçüsü sayılır hale gelmiştir. Baron D'Holbach, Aydınlanma Dönemi'nde ateizmin en temel savunucusu olmuştur. Materyalizmi benimseyen D'Holbach'a göre, insanların ahlakî anlamda çökmüş olması dinden kaynaklanmaktadır.

19. yüzyıldan itibaren ateizm yeni bir kimlik kazanmıştır. Tanrı́nın varlığı, insanı özüne yabancılaştıran, özgürlüğünü kısıtlayan bir problem olarak eleştirilmiştir. Tanrı iradesine karşı insanın özgürlüğü savunulmuştur. Marx, Nietzsche, Freud, Sartre ve Ayer gibi düşünürler modern ateizmin öncüleridir. Materyalizmin mutlak doğru olarak görüldüğü modern dönemde, ateizm bilimsel temeller üzerine oturtulmuş, din de toplumsal bir olgu olarak görülmüştür. ${ }^{16}$

\section{Deizm ve Tarihçesi}

Latincede Tanrı anlamına gelen "deus" kelimesinden türetilmiş olan deizm kavramıyla Grekçede yine Tanrı anlamındaki "theos"tan gelen teizm kavramı aynı manaya işaret etmektedir. Ancak 16. yüzyıldan itibaren Hıristiyan dünyada felsefî ve teolojik tartışmalar başlar. Teizm, artık Ortodoks inançları savunanları, deizm ise geleneksel inançlardan sapanları ifade etmektedir. ${ }^{17} \mathrm{En}$ temel anlamılla deizm, vahyi, peygamberliği ve peygamberlerin bildirdiği Tanrı'yı inkâr ederek yalnızca akılla bilinen Tanrı'nın varlığına inanmaktır. ${ }^{18}$

Pierre Viret, Instruction Chrétienne (Cenova 1564) adlı eserinde, kendilerini ateistlerden ayırmak için deist ismini alan bir grup filozof ve edipten bahsetmiştir. Onları, Allah'a ve evreni Allah'ın yarattı̆̆ına inandıkları halde, İsa Mesih'i ve Hıristiyanlık doktrinlerini inkâr eden ateistler olarak suçlamıştır. 1648 yılında hayatını kaybeden ve İngiliz deizminin babası olarak kabul edilen Lord Herbert, Tanrı'ya ve ahiret hayatına inanmasının yanısıra kutsal metinlerin doğruluğu konusunda ciddi kuşkulara sahiptir. Din adamlığı kurumunu şiddetle eleştirmiş, bunun yanında aklın evrensel gerçekleri kavramaya yeteceğini savunmuştur. 1693'te ölen takipçisi Charles Blount da deist olduğunu açıkça ifade eden ilk düşünürdür ve intiharından sonra yayımlanan A Summary Account of the Deists Religion adlı eseri deist fikirlerin yayılmasında hayli etkili olmuştur. ${ }^{19}$

\footnotetext{
${ }^{15}$ Coşkun, s. 25.

${ }^{16}$ Topaloğlu, ss. 19-23.

${ }^{17}$ Hüsameddin Erdem, "Deizm”, TDV İslam Ansiklopedisi, C: 9, İstanbul 1994, ss. 109-110; Mehmet Aydın, Din Felsefesi, Ankara 1996, s. 173; Taylan, s. 264.

${ }^{18}$ Cevizci, s. 209.

${ }^{19}$ Allen W. Wood, "Kant’ın Deizmi", Çeviri: Necmettin Tan, Ankara Üniversitesi Illahiyat Fakültesi Dergisi, 52 (1), 2011, s. 328; Erdem, s. 110.
} 
Gerek bu eserlerde gerek daha sonrakilerde vurgulanan çeşitli deist tavırlar arasında, aklileştirme çabaları görülmektedir. ${ }^{20}$

Aydınlanma ve modernite çoğunlukla dinin üzerinde konumlandırılmış, hatta din karşıtı bir düşünce olarak ele alınmıştır. Bir adım daha ileri gidilecek olursa Aydınlanma dininin "deizm" olduğu dahi kabul edilmiştir. Zira Paul Hazard'a göre, Aydınlanmanın amacı "Hristiyanlığı sanık sandalyesine koymak", hatta "yaşamın dinsel yorumunu" sona erdirmektir. ${ }^{21}$ Dolayısıyla inancın temelinin öteden beri tahrif edilmiş kutsal metinler değil, akıl olması gerektiği tezi ortaya atılmıştır. Kutsal metinleri yorumlama yetkisine sahip ruhban sınıfı hiyerarşisi reddedilmiş, herkeste ortak bir ölçü olan akıl ile gerçek Hıristiyanlı̆ı̆ı bulunabileceği dillendirilmiştir.

Deizmin bir ekol olarak ortaya çıkmasında İngiltere ve Fransa'daki rasyonalist düşüncenin rolü büyüktür. Vahyin yerini aklın almasıyla yeni bir oluşum ortaya çıkmış, kutsal kitaplar ve mucizeler sorgulanmaya başlanmış, klasik vahiy inancının gereksiz olduğu sonucuna ulaşılmıştır. Bu doğrultuda akıl, dinin geçerliliği konusunda vazgeçilmez addedilmiştir. ${ }^{22}$

Aslında Batı'da görülen ateizm ve deizm gibi din karşıtı akımlar, tepkisel hareketlerdir. Bunun en önemli nedeni; teslis inancı, aslî suç, kiliselerin Tanrı́nın bedeni olduğu anlayışı gibi inançlarla Hristiyanlığın dejenere olmasıdır. Baskı ve korku ile sürdürülebilecek bu iman vasıtasıyla papazlar halk üzerinde mutlak hüküm sahibi olmuş, bu otorite halkın ekonomik anlamda sömürülmesinin de sebebi haline gelmiştir. Modern çağa gelindiğinde sürekli gelişen deneysel bilgi, kilisenin yüzyıllardır savunduğu inançları sarsmış, kilisenin bunu ortadan kaldırmak adına giriştiği baskı politikası ise insanların dinden uzaklaşmasına sebep olmuştur. Hıristiyanlıkta İsa'nın peygamberlikten ilahlığa (Tanrı'nın oğlu ve Tanrı) yükseltilmesi, peygamberlik makamının ruhban sınıfına dağıtılması ve daha pekçok konu esas yörüngesinden çıkarılarak aykırı birtakım yorum ve uygulamalara yol açmıştır. ${ }^{23}$

Deizm düşüncesinde Tanrı́nın dünyaya ve insanlara müdahalesi sözkonusu değildir. Zira deist inanışa göre, Tanrı evreni yaratmış ve öylece terketmiştir. Evrenin ötesinde bulunan ve yaşama müdahale etmeyen Tanrı düşüncesi, teizme ters düşmesine rağmen ateizm olarak da yorumlanmamıştır. Çünkü deistler, teistik bakış açısıyla olmasa da Tanrı fikrini muhafaza ederek ateizmi reddetmişlerdir. ${ }^{24}$ Deizm'de Tanrı, evrenin mutlak kudret ve bilgi sahibi yaratıcısı olarak tasvir edilen, ancak olaylara müdahale etmeyen büyük tasarımc konumundadır. Bu Tanrı, özellikle ihtiyaç duyulduğu anda insanın yanında yer almamakta, kişiden çok evrenle ilgilenmektedir. Söz konusu anlaşılmazlık sebebiyle de yarattıklarına acı çektirmesi, onları yardımından mahrum tutması ve yeryüzünde kötülüğün olması gibi konularda hiçbir zaman sorgulanamayacaktır. ${ }^{25}$

\section{Araştırmanın Bulguları/Kişisel Bilgiler}

Resmî verilere göre Türkiye'de Müslüman olanların oranı \%99'dur. Ancak yapılan araştırmalarda “Allah'ın varlığına ve birliğine, bizi yaratıp yaşattığına inanıyor musunuz?" şeklindeki soruya \%4 oranında "hayır" cevabı gelmiştir. "Evet Allah'ın yarattığına inanıyorum, ama herşeye karıştığını düşünmüyorum."

\footnotetext{
${ }^{20}$ Erdem, s. 110.

${ }^{21}$ Mümin Köktaş, “Aydınlanma, Hristiyanlık ve Deizm”, Anadolu Üniversitesi Sosyal Bilimler Dergisi, 17 (1), 2017, s. 144.

22 Ögcem, s. 108.

${ }^{23}$ Coşkun, "Günümüzde Deizm, Ateizm ve Nihilizmi Doğuran Sebepler", Diyanet Aylık Dergi, 2017 (320), ss. 1112.

${ }^{24}$ Topaloğlu, s. 32.

${ }^{25}$ Emre Dorman, Deizm ve Eleştirisi: Tarihsel ve Teolojik Bir Yaklaşım, Marmara Üniversitesi, Sosyal Bilimler Enstitüsü, (Yayımlanmamış Doktora Tezi) İstanbul, 2009, s.8.
} 
diyenlerin oranı da $\% 6^{\prime}$ dır. Bu rakamlardan yola çıkarak toplumumuzun $\% 4$ 'ünün ateist, $\% 6$ 'sının deist olduğu söylenebilir. Bütün bunların yanında \%4 oranındaki bir grup da karasız konumdadır. ${ }^{26}$

Bu kısa girişten sonra araştırmamızın bulgularına geçiyoruz. İlk olarak ateist ve deist olan deneklerle ilgili kişisel bilgilere yer verilecektir. Her konuyla ilgili istatistiksel bilgiler tablolar halinde aktarılıp, ayrıntılı bir şekilde yorumlanacaktır.

Tablo 1: Cinsiyet

\begin{tabular}{|l|l|l|}
\hline Cinsiyet & Kişi sayısı & Yüzde \% \\
\hline Erkek & 16 & 64 \\
\hline Kadın & 9 & 36 \\
\hline Toplam & $\mathbf{2 5}$ & $\mathbf{1 0 0 , 0}$ \\
\hline
\end{tabular}

\%64'ünü erkek (13 ateist, 3 deist), \%36'sını kadınların (2 ateist, 7 deist) oluşturduğu deneklerin \%96'sı 1925 yaş aralı̆̆ında bulunmaktadır. Bu kategoride yer almayan 1 denek ise 30 yaşındadır. Çalışma, üniversite öğrencileri ekseninde gerçekleştirildiği için deneklerin yaşları birbirine yakındır. Kadın deneklerin oranının erkeklere göre daha düşük olmasının sebebi ise mülakat yapmada çekinken ve isteksiz olmalarıdır.

Ege ve iç Anadolu Bölgesi'nde doğan denekler toplamda \%48'lik katıımla çalışmamızın yarısına yakın bir kısmını oluşturmuştur. Toplam içinde izmir doğumlu olan deneklerin oranı \%20'dir. Akdeniz Bölgesi'nde doğan 4 (\%16) denek vardır. Marmara ve Doğu Anadolu Bölgesi'nde doğan deneklerin oranı \%12 ile birbirine eşittir. Karadeniz Bölgesi'nde doğan 2 (\%8) denek varken Güneydoğu Anadolu Bölgesi'nde doğan 1 (\%4) denek bulunmaktadır.

Deneklerin \%48'i şehirde, \%40'ı büyükşehirde, \%12'si ise ilçede yetişmiştir. Köyde ve yurt dışında yetişen kimse yoktur. Deneklerin ağırlıklı olarak (\%64) yurt dışına çıkmadığı görülmektedir. Yurt dışına çıkanlarsa daha çok Avrupa ülkelerini ziyaret etmiştir. Buna karşılık büyük çoğunluğu (\%84) yabancı dil bildiğini dile getirmiştir. Bu doğrultuda görüş beyan eden deneklerin tamamı İngilizce bilmektedir.

Tablo 2: Anne-Babanın Medenî Hali

\begin{tabular}{|l|l|l|}
\hline Medenî durum & Kişi sayısı & Yüzde \% \\
\hline Birikte & 22 & 88 \\
\hline Boşanmış & 3 & 12 \\
\hline Toplam & $\mathbf{2 5}$ & $\mathbf{1 0 0 , 0}$ \\
\hline
\end{tabular}

Deneklerin, \%88'inin anne ve babası birlikteyken $3(\% 12)$ deneğin anne ve babası ayrıdır.

Anne ve babasının küçük yaştayken ayrıldığını söyleyen Seda Hanım (deist ${ }^{27}$ ), "Psikolojik olarak etkilendiğimi düşünüyorum." şeklinde görüş belirtiyor. Aynı şekilde anne-baba boşanmasına tanık olan Dilan Hanım (deist), ailesinin kendisine karşı "ilgisiz" davrandığını aktarıyor. Uğur Bey (deist) ise "Hayatımı etkileyen en travmatik olay annemle babamın boşanması oldu. Ben küçük yaştayken oldu bu olay, ayrı yaşamaya başladılar." diyerek anlatıyor başından geçenleri.

\footnotetext{
26 Mehmet Ali Kulat, Türkiye'de Toplumun Dine ve Dini Değerlere Bakışı, 12-18 Haziran 2017, s. 4, http://www.makdanismanlik.org/wp-content/uploads/2017/06/MAK-DANI\%C5\%9EMANLIKT\%C3\%9CRK\%C4\%BOYEDE-TOPLUMUN-D\%C4\%BONE-VE-D\%C4\%B0N\%C4\%B0-DE\%C4\%9EERLEREBAKI\%C5\%9EI-ARA\%C5\%9ETIRMASI.pdf, Erişim Tarihi: 09.07.2017.

${ }^{27}$ Çalışmamız hem atesitleri hem de deistleri kapsadığından, deneklerin isimlerinden sonra parantez içinde adı geçenin (ateist veya deist) olduğunu belirten bilgilendirme yapılmıştır.
} 
Deneklerin tamamının annesi hayattayken sadece bir denek, iki yaşındayken babasını kaybetmiştir.

Eğitim açısından bakıldığında ilkokul mezunu annelerin \%24, babaların \%12 oranında olduğu görülmektedir. Ortaokul mezunu babalar (\%32) ise annelerden (\%8) daha fazladır. Lise mezunu annelerin oranı \%28, babaların oranı \%20'dir. Yüksekokul mezunu 1 anne (\%4), 2 baba (\%8) bulunmaktadır. Üniversite mezunu annelerin ( 9 anne) sayısı babalardan (7 baba) fazladır. Annelerin \%36'sı üniversite mezunuyken babalarda bu rakam \%28'dir.

Ebeveynin meslek dağııımı da şu şekilde tespit edilmiştir. Annelerin yarısına yakını (\%48) ev hanımı, \%28'i öğretmen, \%12'si işçi, \%4'ü memur, \%4'ü serbest meslek sahibi, \%4'ü de emeklidir. Babaların ise büyük bir kısmı (\%40) emeklidir. \%16'sı iş̧̧i, \%16'sı tüccar, \%12'si serbest meslek sahibi, \%8'i öğretmen, \%8'i çiftçidir. Öğretmen annelerin sayısı babalardan daha fazladır.

Deneklerin \%60'ı demokratik ve ilgili, \%36'sı yarı demokrat, \%4'ü de (1 kişi) ilgisiz bir aileye sahip olduğunu ifade etmiştir.

Annelerin tamamı İslam dinine mensuptur. Babalardan ise biri deist, biri de ateisttir. Bunların dışında farklı dinî inanca mensup ebeveyn yoktur.

Ateist olan Ebru Hanım babası hakkında şunları söylemektedir: "Babam deist olarak nitelendiriyor kendisini, ama bence o da ateist." "Ben hep deist kalacağımı düşünmüyorum. Belli bir noktadan sonra düşüncem değişir." diyen Yeşim Hanım (deist) ise, daha başka bir konuya dikkat çekiyor: "Babam ateist, ama bunu bildiğimin farkında değil."

\section{İslam Dini ile ilişki}

Tablo 3: Çocuklukta Aile Tarafından Dinî Konularda Bilgilendirilme

\begin{tabular}{|l|l|l|}
\hline Bilgilendirilme durumu & Kişi sayısı & Yüzde \% \\
\hline Evet & 17 & 68 \\
\hline Hayır & 8 & 32 \\
\hline Toplam & $\mathbf{2 5}$ & $\mathbf{1 0 0 , 0}$ \\
\hline
\end{tabular}

Çalışmamızda yer alan deneklerin \%68'i (10 ateist, 7 deist) çocukluk döneminde ailesi tarafından bilgilendirildiğini belirtirken, \%32'si (5 ateist, 3 deist) böyle birşeyle karşılaşmadığını dile getirmiştir.

Atalay Bey (ateist), teşvik edildiğini aktarıyor: "Kültür olarak biz Müslümanlığın dışındayız, aleviyiz. Sadece aleviliğe yönelik değil, 'Namaz da kıl, Kur'an da oku, camiye de cemevine de git.' denildi bana. Camiye de cemevine de gittim."

Annesi Müslüman, babası deist olan Ebru Hanım (ateist), annesiyle babasının bu konuda farklı düşünmesinden dolayı kısmen bilgilendirildiğini belirtmiştir.

Hasan Bey (ateist) ise kendisine din konusunda yeterli bilgilendirmenin yapılmadığını şu gerekçeyle izah etmektedir: "Babam 2 yaşımdayken vefat ettiği için din konusunda annem tarafından baskı görmedim. Herkesin kendi dinini kendi bulabileceği gibi bir düşüncesi vardı, sonuna kadar katıldığım bir düşüncedir."

İsmet Bey (ateist)'in ailesi din konusuyla pek ilgili değildir:

Bizimkiler çok dinle bağlantıları olmayan, çoğu toplumdaki aile yapısına uymayan şekilde yaşıyorlar. Biraz da İzmir'de yaşadıklarından dolayı diyebilirim. İzmir'e bakıldığında \%50'si ateisttir diye bir tabir vardır. Ben turistik amaç dışında camiye gitmedim. Babama "Kur'an' merak ettim, okuyacağım." demiştim, babam dalga geçmişti, "Kur'an mı okuyacaksın?" diye. 
Afrika'daki bir insan açlıktan ölürken başkasının zenginlikle sınanmasının kendisine ters geldiğinden bahseden Volkan Bey (ateist), konuşmasını şöyle sürdürmüştür: "Bizim ailede pek yok. Annem özel günlerde namaz kılar, ama açıktır yani. Onun dışında babamı falan hiç camiye giderken görmedim."

Örnekler, çocuğun dine karşı tutumunun şekillenmesinde ailenin etkisinin önemli olduğunu göstermektedir. Zira çocuğun dinî karakteri ebeveyninden görüp öğrendikleriyle gerçekleşir. ${ }^{28}$

Deneklerimizin \%56'sı İslam dini hakkında yeterli bilgiye sahip olduğunu söylerken \%24'ü bilgisinin yeterli olmadığını dile getirmiştir. \%20'lik bir grup ise kısmen bilgi sahibi olduğunu belirtmiştir. Görüldüğü üzere yeterli bilgiye sahip olduğunu söyleyenlerin oranı (\%56), dinî bilgiyi ailesinden aldığını söyleyenlerin oranından (\%68) azdır. Bu da bize bir kez daha ailesi tarafından bilgilendirilmeyen bireyin daha sonraki dönemde de bu eksiğini gideremediğini göstermektedir. ${ }^{29}$

Hasan Bey (ateist) iddialı bir biçimde yeterli bilgiye sahip olduğunu vurguluyor: "Hatta şu an bile Müslümanım diyen birçok insandan daha fazla bilgiye sahip olduğumu düşünüyorum."

İsmet Bey (ateist) ise yeterli bilgiye sahip olmadığını belirtiyor: "Ben namaz falan bilmem, bir gusül bilirim o kadar. Bir arkadaşım ölmüştü, 17 yaşındaydım, o zaman gitmiştim camiye. Etrafa bakarak, hani sonuçta bir toplum içindesin, yani arkadaşıma saygımdan dolayı, onlarla birlikte ibadeti taklit ettim."

Tablo 4: İslam Dini Hakkında Bilgi Edinilen Yer

\begin{tabular}{|l|l|l|}
\hline Bilgi edinilen yer & Kişi sayısı & Yüzde \% \\
\hline Kur'an kursu & 12 & 48 \\
\hline Aile & 5 & 20 \\
\hline Kendi çabalarımla & 2 & 8 \\
\hline Hiçbir yer & 4 & 16 \\
\hline Diğer & 2 & 8 \\
\hline Toplam & $\mathbf{2 5}$ & $\mathbf{1 0 0 , 0}$ \\
\hline
\end{tabular}

Araştırmamızda yer alan deneklerin \%48'i Kur'an kursuna giderek bilgi edindiğini ifade etmektedir. Kur'an kursuna giden 12 denekten 9'u aynı zamanda anne ve babasından da bilgi aldığını eklemiştir. \%20'si yalnızca ailesinden beslenmiş, \%8'i de kendi çabalarıyla öğrenmeye çalışmıştır. \%16 oranındaki denek grubu ise ailesi dahil hiçbir yerden bilgi almadığını söylemiştir. Diğer seçeneği içinde yer alan iki denekten biri din adamlarından, diğeri de internetten bilgi sahibi olduğunu belirtmiştir.

Kur'an kursuna giden Sinem Hanım (deist), bu tecrübesini şöyle aktarıyor: "Kur'an kursuna gittim, ama yeteri kadar güzel bir eğitim sistemi olmadığını düşündüğüm için çok fazla devam etmedim."

Ozan Bey (ateist) de Sinem Hanım (deist) gibi kısa süreli bir Kur'an kursu tecrübesi yaşamış: "Kur'an kursuna gittim, boğucu geldi ve kaçtım. Bir daha da gitmedim."

Cuma ve bayram namazlarına gittiğini dile getiren Aykut Bey (ateist), din eğitimini ailesinden aldığını ifade ediyor: "Ailem tarafından bilgilendirildim, Kur'an kursuna falan gitmedim, ama çok fazla bilgilendirildiğimi söyleyebilirim. Özellikle okula başlamadan önce annem her şeyi anlatırdı, babam da sure ezberletirdi. Dinle aram çok iyiydi çocukken, hatta ilkokulda yatmadan önce dua ederdim."

\footnotetext{
${ }^{28}$ Antoine Vergote, Çocuklukta Din, Çev: Erdoğan Fırat, Ankara Üniversitesi Ilahiyat Fakültesi Dergisi, 22 (1), s. 316.

${ }^{29}$ Y. Sinan Zavalsız, Din Değiş̧tirmenin Psiko-Sosyal Kodları, Çukurova Üniversitesi ilahiyat Fakültesi Dergisi, Din Psikolojisi Özel Sayısı, 2012 (2), s. 190; Türkiye'de Hıristiyan Olan Müslümanlar: Psiko-Sosyolojik Bir Araştırma (1990-2010), 1. Türkiye Lisansüstü Çalışmalar Kongresi Bildiriler Kitabı, 29 Haziran-01 Temmuz 2012, Konya, s. 175.
} 
İslam dini hakkında hiçbir yerden bilgi almadığını söyleyen Hamdi Bey (deist) ise şunları söylüyor: "Açıkçası ben hiçbir zaman Müslüman olduğumu kabul etmedim. Çocukken bir karar veremiyoruz, Müslümanlık ne bilmiyoruz. Müslümanlığın adını bile bilmiyordum, onun için ben hiç üye olduğumu varsaymıyorum kendi kafamda. Bu yüzden bilgi edinmek için çabalamadım."

Tablo 5: İslam Dini ile Olan Bağ

\begin{tabular}{|l|l|l|}
\hline Din ile bă̆ & Kişi sayısı & Yüzde \% \\
\hline Sıkı bir bağ vardı. & 6 & 24 \\
\hline Zayıf bir bağ vardı. & 8 & 32 \\
\hline Herhangi bir bağ yoktu. & 11 & 44 \\
\hline Toplam & $\mathbf{2 5}$ & $\mathbf{1 0 0 , 0}$ \\
\hline
\end{tabular}

Daha önce mensup olduğunuz din ile aranızdaki ilişki nasıldı?" diye sorulan soruya deneklerin \%24'ü (5 ateist, 1 deist) sıkı bir bağ olduğu şeklinde cevap vermiştir. Bu cevabı veren 6 kişiden biri dinî yükümlülüklerini yerine getirmeye çalıştı̆ıını, biri de Allah'a sürekli dua ettiğini belirtmiştir. Deneklerin \%32'si (4 ateist, 4 deist) İslam dini ile arasındaki ilişkinin zayıf ve yüzeysel olduğunu, hatta ismen Müslüman olduğunu vurgulamıştır. \%44 oranındaki (6 ateist, 5 deist) denek grubu ise i̇slam dini ile arasında herhangi bir bağ olmadığını ifade etmiştir.

Deneklerin İslam dini ile kurduğu bağın daha iyi anlaşıması açısından aşağıdaki örnekler açıklayıcı olacaktır.

Sinem Hanım İslam dini ile arasındaki bağı şöyle anlatıyor:

Deist olmadan önce yalvarma, dua etme, sığınma içgüdüsüyle bağlıydım... Yapmış olduğun duaların karşılığını ne zaman alacağına dair beklenti içinde oluyorsun ya, bende de öyleydi, çok bağlıydım... Fakat beklentilerimin karşılandığını düşünmüyorum, o zaman da düşünmüyordum, tesadüf üzerine gerçekleşiyordu sanki. Tanrı kavramı bende o izlenimi oluşturdu. Ben dua ederim, duamı kabul eder, zaten böyle bir algı vardır ya, ne istersen Allah'a dua edeceksin ve o sana bunun karşıı̆ı̆ını muhakkak bir gün verecek. 30 sene geçti hala bir karşılık alamadım.

İslam dini ile arasında aşırı bir bağ olmadığını söyleyen Doğan Bey (ateist) şunları söylüyor:

Çok fazla aşırı bir bağ yoktu hiçbir zaman, ama anlatılanları hep dinlerdim. Kendi mantığımın yettiğince açıklama yapardım. Aklımda bir sürü soru işareti vardı, çok fazla soru sorardım. Bu soruların karşıı̆ı̆ıı da bir yere kadar aldım. Aldığım sürece de o dine mensup olmaya devam ettim, karşııık alamadıktan sonra bıraktım.

Aslan Bey (ateist), daha önce mensup olduğu dinle arasındaki bağın en başından beri saçmalık üzerine kurulu olduğunu, dinlerin mucize olarak adlandırdığı olayları anlayamadığını dile getirmektedir: "Gökten bir koyunun indiğine nasıl inanabilirdi bir beyin? Hz. Nuh dedikleri gibi gemiye her canlıdan iki tane almıs, Afganistan sınırlarında oluyor bu olay. Penguenle kutup ayısını nereden bulmuş, bu benim aklımda bir soru işaretidir."

İslam dinini hiçbir zaman yoğun yaşamadığını, dinin sömürülmesinden dolayı ateizme yöneldiğini belirten Ebru Hanım ise şöyle aktarıyor:

Hiç yoğun yaşamadım dini. Bir olay anlatayım, Kuran kurslarına giderdi kuzenlerim, ben de çok gitmek isterdim. Küçüktüm 5-6 yaşlarında. Babam çok yollamak istemezdi, annem de çok karşı çıkmazdı. Babam bir gün göreyim diye yolladı. Kısa kollu ve şortla gittim, hoca beni 
kovdu camiden. "Böyle gelemezsin, yarın böyle gelme, arkadaşların gibi gel." dedi, daha da gitmedim.

Alevi kökenli deneklerimizden Yeşim Hanım (deist), dinin kendisine saçma geldiğini, özellikle sağlık açısından doğru bulmadı̆̆ını beyan etmektedir:

Bir keresinde Adanalıların cem törenine gittik. Yaşlı bir adam büyük bir kaptan ağzını değidirerek su içiyor, dede olduğunu söylüyorlar onun. Sonra o suyu bardaklara doldurarak insanlara dağıtıyorlar. Bu adam sağlıklı mı?... Tükürük temas ediyor. Bu dinde niye olsun?... Başkasının içtiği bir suyu içmek bana ne gibi bir kazanç sağlayabilir, bu bana çok saçma gelmişti o zaman.

Araştırmada yer alan deneklerden hiçbirisi herhangi bir cemaate mensup değildir. Ancak 4 denek daha önce cemaat ortamında bulunduğunu dile getirmiştir. Ümit Bey (ateist), ailesinin çok karşı çıkmasına rağmen bir dönem derslerini düzeltmek adına abilere gittiğini ifade etmiştir. Uğur Bey (deist), cemaat sohbeti sayılmasa da bir kez bir abi vasıtasıyla dini sohbete gittiğinden, bir evde toplandıklarından bahsetmektedir.

Araştırmamıza katılan deneklerin \%44'ü ailesinin İslam dini ile ilgili ibadetleri yerine getirme konusunda kendisine destek olduğunu, teşvik ettiğini ve tavsiyelerde bulunduğunu söylemiştir. \%56'sı ise ailesinin kendisine bu konuyla ilgili hiçbir şey söylemediğini beyan etmiştir.

Çalışmamıza katılan denekler, genel olarak ibadetler konusunda annelerinin teşvik ve destek noktasında müdahalede bulunduğunu, babalarının ise çok fazla karışmadığını belirtmeektedir. Ayrıca deneklerin büyük bir kısmı annesinin ibadetlerini yerine getirmeye çalıştığını, dinin emirleriyle daha alakadar olduğunu beyan ederken babasının ise Cuma ve Bayram namazlarına gittiğini vurgulamaktadır.

\section{Ateist veya Deist Olma Süreci}

Bu bölümde deneklerin ateist veya deist olmadan önce mensup olduğu dinde ibadet etme sıklığı, toplumla ilişkisi ve ebeveynin din anlayışı incelenecektir. Ardından önceki süreçte, İslam ile ateizm veya deizm düşüncesine karşı sergilenen tutum, inançlı olunan dönemde cemaat mensubiyetinin olup olmadığı, herhangi bir siyasi düşüncenin benimsenip benimsenmediği konuları ele alınacaktır. Son olarak ateist veya deist olma yolu, bağıı bulunulan dinin dışında farklı bir din arayışı olup olmadığı konusu irdelenecektir.

Tablo 6: Ateist veya Deist Olmadan Önce İslam Dinine Ait İbadetleri Yerine Getirip Getirmeme Durumu

\begin{tabular}{|l|l|l|}
\hline ibadetleri yerine getirme & Kişi sayısı & Yüzde \% \\
\hline Sürekli & 1 & 4 \\
\hline Ara sıra & 8 & 32 \\
\hline Bazı ibadetleri & 4 & 16 \\
\hline Bir dönem & 4 & 16 \\
\hline Hayır & 8 & 32 \\
\hline Toplam & $\mathbf{2 5}$ & $\mathbf{1 0 0 , 0}$ \\
\hline
\end{tabular}

Araştırmamızda yer alan deneklerin \%4'ü (1 deist) i̇slam dinine ait ibadetleri sürekli olarak yerine getirdiğini, \%32'si (6 ateist, 2 deist) ara sıra ibadet ettiğini, \%16'sı ( 3 ateist, 1 deist) bazı ibadetleri yerine getirdiğini, \%16'sı (1 ateist, 3 deist) bir dönem ibadet ettiğini dile getirirken \%32'si ( 5 ateist, 3 deist) hiçbir şekilde ibadet etmediğini belirtmiştir. Hiç ibadet etmeyenlerle, ibadetlerini bir dönem ya da arasıra gerçekleştirenlerin oldukça yüksek (\%96) bir orana sahip olması deneklerin inançlı oldukları dönemde ibadet etme konusunda gevşek davrandıklarını ortaya koymaktadır. 
Ibadetlerinin sürekli olarak yerine getirdiğini söyleyen Ziya Bey (deist) şöyle söylüyor: "ilk başlarda lise sonuna kadar 7-8 yıl kadar çok az vakit kaçırırdım, sıklıkla yerine getirirdim ibadetlerimi. Oruç hiç kaçırmazdım."

Can Bey (ateist) ise, bazı haftalar sektirmekle birlikte Cuma ve bayram namazlarına gittiğinden bahsediyor. Küçükken oruç tuttuğunu, ancak ateizm düşüncesiyle beraber bu ibadetten de vazgeçtiğini dile getiriyor.

Burcu Hanım (deist), "Beş vakit namaz hiç kılmadım, hatta lise dönemlerimde ailemin 'Bugün kandil, namaz kıl.' şeklindeki teşvikiyle 1-2 namaz kıldığım oldu. Sonrasında onu da bıraktım. Oruç tutardım, tutmaya çalışırdım, o şekilde." diyerek bazı ibadetleri yerine getirdiğini anlatıyor.

Babasıyla ilişkisinin çok iyi olmadığını dile getiren Tolga Bey (ateist) ise dinî ritüellerden uzak olduğunu vurgulamıştır: "Hiç yapmadım diyebilirim. Namaz kılmadım, camiye hiç gitmedim hayatım boyunca. Orucu da küçükken belki 1-2 gün tutmuşumdur. O zamanlar babaannem tutuyordu. Onlar ne yapıyorsa ben de onu yapıyordum."

ibadetleri yerine getirmediğinden bahseden Aslan Bey (ateist) de "Çocukluğumdan beri saçma bulduğum için yerine getirmiyorum. Fakat teravihe gidip oradaki ortamı teneffüs etmişliğim vardır." şeklinde izah ediyor durumu.

Araştırmamıza katılan deneklere ateist veya deist olmadan önce toplumla ilişkilerinin nasıl olduğu sorulmuş, \%96'sı toplumla ilişkilerinin gayet iyi olduğunu, hiçbir sıkıntı yaşamadığını belirtmiştir. Sadece 1 kişi (\%4) çekingen davrandığını beyan etmiştir.

Tablo 7: Ateist veya Deist Olmadan Önceki Ateizm veya Deizm Düşüncesi

\begin{tabular}{|l|l|l|}
\hline Ateizm veya Deizm imajı & Kişi sayısı & Yüzde \% \\
\hline Olumluydu & 9 & 36 \\
\hline Olumsuzdu & 10 & 40 \\
\hline Fikrim yoktu & 5 & 20 \\
\hline Araştırıyordum & 1 & 4 \\
\hline Toplam & $\mathbf{2 5}$ & $\mathbf{1 0 0 , 0}$ \\
\hline
\end{tabular}

Deneklerin önceki süreçte ateizm veya deizm hakkındaki düşüncesi \%36 olumlu, $\% 40$ olumsuzdur. Ayrıca \%20'si o dönemde herhangi bir fikri olmadığını, \%4'ü de araştırdığını söylemiş̧tir. Olumsuz fikre sahip 10 denekten sekizi ateist, ikisi deisttir. Olumlu fikre sahip olanlarınsa tamamı deisttir.

Olumlu düşünce sahibi denekler çocukluk döneminden itibaren zihinlerinde sorgulamanın olduğunu belirterek ateizm veya deizm düşüncesiyle karşılaştı̆ı̆ında bir olumsuzluk yaşamadığını açıklamıştır.

Zihninde ateizm veya deizm düşüncesinin olumsuz olduğunu söyleyen 10 denekten ikisi çevresindeki ateist ve deistleri dine davet ettiğini söylerken, biri ateistlerden, biri de ateist olmaktan korktuğunu belirtmiştir.

Atalay Bey zihnindeki ateizm düşüncesini şöyle ifade ediyor: "Korkuyordum aslında, ateist olduktan sonra korkuyla büyüdügümü fark ettim. Onu yaparsan günah, bunu yaparsan sevap gibi. Onların cezalandırılacağını, cehennemde yanacağını düşündüğüm için korkuyordum. Ateistlerden değil, ateist olmaktan korkuyordum."

Deizm düşüncesi hakkında fikrinin olmadığını dile getiren Yeşim Hanım'ın aktardıkları da şöyle: "Bilmiyordum, önce bende bir düşünce oluştu. Daha sonra internetten baktığımda bu düşüncenin adının deizm olduğunu öğrendim. Direkt deizmi duyup bu düşünceyi savunayım demedim."

Ateizm veya deizm konusunda fikrinin ve bilgisinin olmadığını söyleyen diğer 3 denek de tıpkı Yeşim Hanım gibi zihinlerindeki düşüncenin bir karşılığının olduğunu araştırma sonucu elde ettiklerini söylüyor. 
Deneklerin önceki süreçte sahip olduğu ateizm veya deizm imajını, alınan eğitimin, yetiştirilme tarzının, bulunulan çevrenin, sahip olunan dinî bilginin şekillendirdiğini görmekteyiz. Zira çocukluk döneminde ailesi tarafından dini konularda bilgilendirilmediğini söyleyen 9 deneğin altısının zihnindeki ateizm veya deizm düşüncesi olumludur.

Tablo 8: Politik Bir Organizasyonda Yer Alma

\begin{tabular}{|l|l|l|}
\hline Siyaset bağlantısı & Kişi sayısı & Yüzde \% \\
\hline Evet & 16 & 64 \\
\hline Hayır & 9 & 36 \\
\hline Toplam & $\mathbf{2 5}$ & $\mathbf{1 0 0 , 0}$ \\
\hline
\end{tabular}

Deneklerin \%64'ü siyasî bir düşünceye sahipken \%36'sı böyle bir organizasyonun içinde yer almadığını ifade etmiştir. Buna göre herhangi bir siyasî düşünceyi benimseyen 16 denekten sekizi sosyalizme, ikisi CHP’ye, dördü Atatürkçülüğe, biri ise Türkçülüğe gönül vermiştir. 1 denek ise siyasî bağlantısı olmasına rağmen adres belirtmemiştir. Siyasetle bağı olmadığını söyleyen 2 denekten biri annesi istediği için CHP’ye oy verdiğini, bunun dışında çok bulaşmadığını, diğeri de çok net bir siyasî ideolojisi olmasa da kendisini daha çok sol ideolojilere yakın hissettiğini belirtmiştir. Tüm rakamlar bir araya getirildiğinde deneklerin en az \%64'ünün sol ideolojilere mensup olduğu ortaya çıkmaktadır.

Aykut Bey (ateist), 1970'ler CHP'sini benimsediğini vurguluyor. İmirli olduğunu belirten Hasan Bey (ateist), İzmir'in solcu olduğunu, kendisinin de ailesinin izinden giderek sol bir görüşü benimsediğini dile getiriyor.

Marksizmi benimsediğini söyleyen Nihat Bey (ateist), dünyayı işçilerin yönetmesi gerektiğini ifade ediyor. Ümit Bey (ateist) de sosyalist bir ülkeye inandığını beyan ediyor: "Sovyetler Birliği 80-85 yıl boyunca ayakta kaldı. O dönemde insanlar dinlerini özgürce yaşayabildiler. Küba'da insanlar Hıristiyan, yine bir eziyet görmemişler."

Esra Hanım (deist), siyasetten nefret ettiğini, ancak "AKP dışındaki her ideolojiye sahip olabileceğini" aktarıyor. Herhangi bir siyasî düşünceyi benimsemediğini söyleyen Doğan Bey (ateist) ise vatan sevgisine vurgu yapıyor: "Benim siyasi görüşüm şudur; hepimiz bu ülkenin evladıyız. Hangi ırktan olursak olalım, ülkemizin değerini bilelim. Ortak nokta vatan sevgisinde birleşmektir."

Tablo 9: Ateist veya Deist Olma Yolu

\begin{tabular}{|l|l|l|}
\hline Karar verme & Kişi sayısı & Yüzde \% \\
\hline Kur'an'ı sorgulayarak & 8 & 32 \\
\hline Müslümanları sorgulayarak & 5 & 20 \\
\hline Ateist veya Deistler vasıtasıyla & 4 & 16 \\
\hline Bilim ve felsefe okuyarak & 3 & 12 \\
\hline Yaratılışı sorgulayarak & 3 & 12 \\
\hline Kendime uygun din arayarak & 2 & 8 \\
\hline Toplam & $\mathbf{2 5}$ & $\mathbf{1 0 0 , 0}$ \\
\hline
\end{tabular}

Deneklerin \%32'si Kur’an'ı sorgulayarak, \%20'si Müslümanları sorgulayarak, \%16’sı ateist veya deist insanlar vasıtasıyla, \%12'si bilim ve felsefe okuyarak, \%12'si yaratılışı sorgulayarak, \%8'i de kendisine uygun dini ararken ateizm veya deizmle tanışmıştır. Deneklerin sorgulama ve araştırma biçimlerini kendi anlatımlarıyla örneklendirmek faydalı olacaktır. 
Seda Hanım, Kur'an kursuna gitmeye başladıktan sonra mensup olduğu dinden uzaklaşmaya başladığını vurguluyor: "Kur'an okumaya başladıktan sonra, ayetleri anlamaya başlayınca, onun bir insan tarafından yazıldığını ve uydurma olduğunu düşünmeye başladım. Daha çok çıkar için yazıldığı kanısına vardım. Araştırmalarımdan sonra deist olmaya karar verdim."

Müslümanları sorgulayarak deizmle tanıştığını söyleyen Burcu Hanım, ailesinin dinî yaşantısını sorguladığını söylüyor:

Bunun bir başlangıcı olmadı. "Ben şöyle bir insan mıyım, evet böyle bir insanım, o zaman ben deistim." olmadı. Öğretiler vardı ve ailemi örnek alarak yaşamaya çalışıı bu konuda. Ailem inanan insanlardı, ama bir şeyleri yerine getirmediklerini gördüm. Evet Müslümanlardı, ama Müslüman olmanın koşullarını yerine getirmiyorlardı. Babam mesela sadece cumadan cumaya namaz kılan bir insandır. Annem de kandillerde kılar. Onlar yerine getirmiyorlardı, ama mesela bunu sorgulamaya kalktığımda hayır sorgulanmaz, hayır yapılmazlar ile karşılaştım. Bunun sorgulamama kısmını sorgulamaya başladım ve o şekilde gelişiyor bir şeyler. Duyduklarım, okuduklarım, öğretiler falan.

Sinem Hanım (deist) da çocukluktan beri sorguladığını belirtiyor: "Aslında Allah'ın var olduğuna her zaman inandım. Ama o kadar mükemmel bir varlığın bu kadar kötü bir sistem yaratıp insanlara vahiy yoluyla birşeyler gönderdiğini zannetmiyorum, insanlara müdahalesinin olduğunu düşünmüyorum. $O$ yüzden çocukluktan beri deist olduğumu söyleyebilirim."

Ateizmle tanışmasının ateist insanlar vasıtasıyla olduğunu söyleyen Atalay Bey, çevresindeki ateist bireylerin yaşantısıyla kendi yaşantısını karşılaştırdığını vurguluyor:

Çevremdeki ateistler için korkuyordum zaman zaman, bir süre sonra onların korkmadığını, korkusuz olduğunu fark ettim. İyi de insanlardı, sadece inanmıyorlardı. Ben bir şey yaparken sevap olduğu için yapıyordum, onlar iyi olduğu, etik olduğu için yapıyordu. Yapmadıkları şeyleri de etik olmadığı için yapmıyorlardı. Onlarda sevap-günah, cezalandırılmak yoktu. Ben bir hayvanı beslemeyi sevap olduğu için yapıyorken onlar insanî duygular gereği yapıyordu. Bunu fark ettim, daha mantıklı geldi. Ondan sonra zaten araştırmaya başladım, kötü bir şey olmadığına karar verdim.

Ateizm ile tanışmasının felsefeyle başladığını söyleyen Nihat Bey ise Nietzsche okuduğunu belirtiyor:

Ateizmle ile tanışmam "Tanrı öldü." sözünün sahibi Nietzsche ile oldu. Bir lise öğrencisi için devasa yazıtları olan Nietzsche'nin Böyle Buyurdu Zerdüşt, Şen Bilimleri, İnsanca Pek İnsanca, gibi eserlerini okudum. Sonra da dinler tarihini araştırdım. Kur'an'ı okudum. Mukaddes kitabın oluşma sürecini araştırdım. Sonra da edebiyat ve siyaset alanına yöneldim. Siyasî bir gücün elinde din faktörünün nasıl etkili olduğunu Gorki'den, Dostoyevski'den, Aldouis Huxley'den vs. gördüm. Hayatıma Turan Dursun girdi. Çok zor bir dönemde bile birçok dinci gruba bilgisiyle kafa tutan bu mükemmel yazarı okudum. Turan Dursun'un katledilişi, dinlerin insan elinde ne tür bir canavara dönüşebileceğini gösterdi bana. Ben de artık insanın hiçbir tahakküm altında olmadan yaşayabileceği bir hayatı kabul ettim. "Ne vaatler ne de cezalar benim istemsizce geldiğim bu dünyada bana hayatımı nasıl yaşayacağımı söyleyemez." diye düşündüm ve ateist oldum.

Varoluş ve maddeyi sorguladıkça ateizme doğru bir yöneliş yaşadığını dile getiren Aykut Bey şunları anlatmaktadır:

Biyoloji konusunda bilgi sahibi oldukça (hücre bölünmesi, hücre gelişimi, protein sentezi, canlıı̆ın gelişimi ve ilerlemesi, evrenin oluşumu), evrimin nasıl ilerlediğini gördükçe, 
...Ortaçağ'da bilimin nasıl engellendiğini, kiliselerin evrim konusunu nasıl kapattığını gördükçe ...bir ilahî güçten daha çok maddesel kavramları mantıklı bulmaya başladım. Zamanla yaratıcı kavramı bana mantık dışı gelmeye başladı.

Varoluş ve yaratııışı sorgulayarak ateist olduğunu söyleyen Ümit Bey, bilimin ilerlemesiyle zihnimizdeki soruların cevaplanacağını söylüyor:

Maddeyi ve insanı tanıdıkça, sosyolojik olarak insanlık tarihini okudukça şöyle düşünmeye başladım; ilkel dinlere baktığımız zaman insan açıklayamadığı şeylerden korkuyor. Bilim hep vardı insanlık tarihi boyunca. Fakat algılayamadığı için açıklayamadığı şeyleri metafizik olaylarla açıklamaya çalışıyor... Deniz kenarında yaşayan toplumlar fırtına olduğu zaman deniz tanrısı sinirlendi diyorlar. Ateşi bilmeyen insanlar ateşin mucizesine hayran kalıp ateşe inanmaya başlıyorlar... Insanlar açıklayamadığı şeylere inanma ihtiyacı hissediyor. Çünkü insan güçsüz, evreni çözümlemeye çalışıyor, içinde yaşadığı dünyayı algılamaya çalışıyor. Bu noktada bunu gördükçe, şu an ateşe tapıyor muyuz? Tapmıyoruz. Çünkü belli başlı şeyler açıklandı ve dinlere de insanlar bu şekilde adapte olmaya başladı. Eğer ki insanın nasıl oluştuğu açıklanabilirse, bence bu da ortada kalmayacak. Bu bilimin yeterliliği ile ilgili bir şey. Biraz da bunun farkına vararak ateist oldum.

Tablo 10: Travmatik Bir Olay Yaşayıp Yaşamama Durumu

\begin{tabular}{|l|l|l|}
\hline Travmatik olay & Kişi sayısı & Yüzde \% \\
\hline Evet & 8 & 32 \\
\hline Hayır & 17 & 68 \\
\hline Toplam & $\mathbf{2 5}$ & $\mathbf{1 0 0 , 0}$ \\
\hline
\end{tabular}

Araştırmamıza katılan deneklerin \%32'si travmatik bir olay yaşadığını dile getirirken \%68'i böyle bir tecrübesi bulunmadığını belirtmiştitr.

Soruya "evet" şeklinde cevap veren Sinem Hanım (deist) çok ciddi bir trafik kazası geçirdiğini anlatıyor:

Bu zaten hayatımın en önemli olayı, dönüm noktası diyebilirim. Aslında çoğu insan bunu şöyle algılıyor. Öldürmeyen Allah öldürmüyor, yaşatmak isteyen Allah yaşatıyor. Beni bir hastalıktan kurtarmak isteyen Allah kurtarıyor gibi. Ama orada çok önemli 20 hekim ile girmiş olduğum 10 buçuk saatlik ameliyat vardı. Bu insanlar gerçekten bilime yıllarını vermiş insanlar, beni onların kurtardığını düşünüyorum. Allah ile bir bağlantısının olduğunu zannetmiyorum.

Dinden uzaklaşma anlamında travmatik bir tecrübeye sahip olduğunu aktaran Volkan Bey (ateist) de ölüm olgusuna vurgu yapiyor:

Selim abim öldü, dedem öldü, bir de bir ay önce yeğen öldü bizim, 17 yaşındaydı. Bence hakkı yoktu ölmeye. Bir de yeğenimin yaşadığı yer Gönen, orası bayağı inanan bir toplum. Olay oldu, 15 gün yoğun bakımda kaldı. İyileşsin diye dua ettiler. Öldüğünde de kaderi böyleymiş diye kendilerini teselli ettiler. Yani anlamıyorum aradaki şeyi.

Ziya Bey (deist) yaşadığı travmatik tecrübenin düşünmeye sevkettiğini söylüyor:

Şiddeti ne kadar travmaya yakın tartışılır, ama lise döneminde birisinin benim yüzümden intihar ettiği gibi saçma sapan bir şey gelmişti kulağıma. Başarısız olmuştu girişimi. Bir de şiddetli ailevî sorunlar oldu biraz. 


\section{Bunların inanç değişikliğini tetiklediğini söyleyebilir miyiz?}

Yani, kısmen \%30-40 civarı diyelim ona. Çok değer verdiğin insanların senden gitmek istemesi özellikle anne-baba seni düşünmeye sevk ediyor.

Uğur Bey (deist)'i en çok etkileyen olay ise henüz küçükken anne-baba boşanmasına tanık olması: "Ayrı yaşamaya başladılar, bunu söyleyebilirim." Seda Hanım (deist) da Uğur Bey gibi anne ve babasının küçük yaşta ayrıldığını belirtiyor. İsmet Bey (ateist), genç yaşta bir arkadaşını trafik kazasında kaybetmiş. Hamdi Bey (deist), annesi çalışıı̆ı için kendisine anneannesinin baktığını ve onun ölümünün kendisinde travmatik etki oluşturduğunu ifade ediyor.

Travmatik olay yaşadığını söyleyen denekler genel hatlarıyla trafik kazası, yakın akraba ve arkadaş vefatı, anne-baba boşanmasına tanık olma ve anne babayla sıkıntılı ilişkiler gibi konuları öne çıkarmışır.

Ateist deneklerden biri (Hasan Bey) ise travmatik olaylar yaşadığı halde bunlardan etkilenmediğini belirtmiştir. "Genç yaşta babasız kaldım. Hayatımdaki en büyük dramatik olay buydu. Ama hiçbir şekilde görüşümü etkilemedi." Hasan Bey'in yaşadığı travmanın boyutu, en az travmadan etkilenen deneklerin yaşadığı kadardır.

Aile ilişkilerinin dengesiz ve düzensiz olması, anne-babanın boşanması, çok sevilen bir yakının vefatı, trafik kazası, cinsel istismara maruz kalma vs. gibi olaylar şok tepkisi denilen geçici kişilik bozukluklarına neden olabilir. Bu olayların etkileri bazı insanlarda uzun süreli kişilik bozukluğu olarak ortaya çıkar. Şok tepkisi belirtileri, olayın şiddetine, türüne, beklenmedik bir anda ortaya çıkmasına ya da önceden hazırlıklı olunmasına ve olayı yaşayan bireyin kişilik yapısına bağlı olarak değişebilir. ${ }^{30}$

Sosyal dünyanın dengesiz algılanması bireye din değiştirme konusunda etki eden etmenlerdendir. Kişi böyle durumlarda kimlik bunalımına, hayatın anlamsızlaştığı düşüncesine kapılabilir. Yaşanan travmatik olaylar, bireyin dini anlamda değişim yaşamasına sebep olabilir. ${ }^{31}$

Tablo 11: Ailede ve Çevrede Başka Ateist veya Deist Olup Olmama Durumu

\begin{tabular}{|l|l|l|}
\hline Ailede, çevrede ateist veya deist & Kişi sayısı & Yüzde \% \\
\hline Evet & 18 & 72 \\
\hline Hayır & 7 & 28 \\
\hline Toplam & $\mathbf{2 5}$ & $\mathbf{1 0 0 , 0}$ \\
\hline
\end{tabular}

Deneklerin büyük çoğunluğunun (\%72) ailesinde ya da çevresinde ateist veya deist bir tanıdığı vardır. \%28'lik grupta ise böyle bir tanıdık söz konusu değildir. 7 deneğin hem ailesinde hem de çevresinde ateist veya deist bireyler mevcut iken, ailesinde kendisinden başka babası, kardeşi, dayısı ve kuzeni ateist veya deist olan denekler bulunmaktadır.

Ailesinde ve çevresinde ateist veya deistlerin bulunduğunu söyleyen 18 denekten $11^{\prime} i$ ( 8 ateist, 3 deist) onlardan etkilendiğini beyan etmiştir. Etkilenme, düşüncelerin değişmesi ve sorgulanması anlamında olduğu gibi deneklerin çevresindeki ateist veya deist bireylerden cesaret alması anlamında da gerçekleşmiş̧ir.

Babasının deist olduğunu söyleyen Ebru Hanım (ateist) babasından etkilendiğini gizlemiyor:

Ailemde ve akrabalarım arasında yok, arkadaşlarım arasında var. Babam deist olarak nitelendiriyor kendini, ama bence o da ateist.

\footnotetext{
${ }^{30}$ Engin Geçtan, Psikodinamik Psikiyatri ve Normal Dışı Davranışlar, ìstanbul 1992, s. 208.

${ }^{31}$ Zavalsız, Türkiye'de Hıristiyan Olan Müslümanlar: Psiko-Sosyolojik Bir Araştırma (1990-2010), Ankara 2017, s. 290.
} 


\section{Babanızın size etkisi oldu mu?}

Babam beni etkilemedi diyemem, ama bence olumsuz bir etkilenme değil bu.

Kendisi deist olan Uğur Bey de babasının 10-15 yıl öncesine kadar ateist olduğunu, geçirdiği bir kaza sonrasında Müslüman olduğunu anlatıyor.

Tolga Bey (ateist) ailesinden şöyle bahsediyor: "Dayım var, ama ona da sorsan söylemez belki. Anne tarafım inanış açısından (dedem, dayılarım, teyzemleri tam bilmiyorum) daha çok ateist hareketleri gösteriyorlar, o tarzda görünüyorlar, inanışları yoktur."

Ateist olan Atalay Bey, bu konuda şunları dile getiriyor:

Kuzenlerim ateist, onların dışında çevremde, oturduğum mahallede genel anlamda benim yaşıtlarımın \%80-90'ı ateisttir.

\section{Onların size etkisi oldu mu?}

Sen de ateist ol, diye bir çağrı olmadı. Ateist olmadığım için beni dışlamadılar. Gözlemlerim kadarıyla etkilendiğim oldu.

Aslan Bey ise kendisinden önceki kuşakta hiç ateist olmadığını, ama kendisinden sonra aşağı yukarı kuzenlerinin hepsinin ateist olduğunu aktarıyor.

Neredeyse hiç namaz kılmadığını ve oruç tutmadığını ifade eden Hamdi Bey (deist) ise arkadaşlarıyla yaptığı sonu gelmez tartışmalardan bahsediyor:

Biz hep beraber birbirimizi deist yapmış da olabiliriz. Mahallede akşam çıkardık, varoluşsal bir soru bir kere soruldu mu arkasından, kimse bir şey bilmese de herkes kendi mantığına göre konuşurdu. Bunun üzerine bunu tartışa tartışa, 8 yıldır tartışıyoruz belki. Tartışa tartışa bir şeylere varmaya çalıştık, ama bir sonuca varamadık. Fakat doğru yeri bulmaya çalıştık. Ahlaklı olmak için Müslüman olmanın gerekmediğini düşündük. Bu şekilde birbirimizi etkilediğimiz söylenebilir.

\section{Ateist veya Deist Olduktan Sonraki Durum}

Deneklerin \%96'sı ateizm veya deizme ergenlik ve gençlik dönemi adı verilen 12-21 yaş arasında geçerken 1 denek (\%4) ilk yetişkinlik olarak isimlendirilen 22-40 yaş arasında deist olmuştur.

Ateizm veya deizmle ilgili bilgi düzeyleri \%24 çok iyi, \%60 yeterli, \%12 orta, \%4 zayıf şeklinde ölçülmüştür. $\% 76$ 'sı ateizm veya deizme uyum sağlamakta zorlanmadığını, \%24'ü ise sıkıntı yaşadığını belirtmiştir.

Deneklerin büyük çoğunluğunun mensup olduğu dinle arasındaki bağın zayıf olması sebebiyle ateizm veya deizme uyum sağlama noktasında sıkıntı yaşamadığını söyleyebiliriz. Ateizm veya deizme uyum sağlama noktasında sıkıntı yaşadığını söyleyen denekler ise genel olarak geçiş aşamasında ve karar verdikten sonraki süreçte bir dönem sıkıntı çektiğini, daha sonra alıştığını belirtmiştir.

Tablo 12: Deneklerden Etkilenerek Ateist veya Deist Olma

\begin{tabular}{|l|l|l|}
\hline Deneklerden etkilenme & Kişi sayısı & Yüzde \% \\
\hline Evet & 14 & 56 \\
\hline Hayır & 11 & 44 \\
\hline Toplam & $\mathbf{2 5}$ & $\mathbf{1 0 0 , 0}$ \\
\hline
\end{tabular}


Deneklerin ateist veya deist olduktan sonra başkalarına etkisi olup olmadığını irdelediğimiz bu soruya verilen cevapların \%56'sı evet, \%44'ü hayır şeklinde ortaya çıkmıştır. Denekler, genel olarak karşısındaki insanı düşünmeye ve sorgulamaya itecek şekilde, başkaları üzerinde etkisi olduğunu ifade etmiştir.

Bayağı kişiyi etkilediğini söyleyen Uğur Bey (deist), Müslümanken ateist bir arkadaşını Müslüman yaptığını dile getiriyor:

Onu camiye götürdüm, dua ettirmeye başladım, Müslüman oldu. Bu olayın ardından bir sene sonra ben deist oldum, deist olduktan sonra da bu sefer Müslüman arkadaşlarımla tartışmaya girmeye başladım. Onlarla tartıştıkça, bazı kitaplar okuttukça, bazı belgeseller izlettikçe onları da deizme çektim. Yaklaşık 7-8 kişiyi deizme çekmişimdir.

Nihat Bey (ateist) ise arkadaşlarının kendisini takip ettiğini aktarıyor: "Ben bildiklerimi paylaşmayı seven bir insanım. Bildiklerimi paylaştığımdan ötürü iki arkadaşım önce ateist sonra da deist oldu. Var herkeste bir yaratıcı özlemi."

Başkalarına etkisinin olduğunu dile getiren deneklerden birisi de Aslan Bey (ateist):

3-4 yıl önceye kadar arkadaşlarıma ateizmi tanıtıyordum. "Biraz sorgulasana, neden böyle yapıyorsun?" gibi. Sonra bu çocukların aile ilişkilerinde ciddi anlamda sıkıntılar yaşadığını fark ettim. Ben bu durumu aileme anlatabilmiştim, ama onlar anlatamadılar. Sonra dedim ki "Benim bunu yapmamam lazım, çok yanlış bir şey." Bana dinimi soruyorlar, "Ateistim." diyorum. "Nasıl böyle oldun?" diyorlar, hiçbir yorum yapmıyorum. Çünkü biliyorum ki karşıma aldığım insanı az çok ikna edebilirim, dini duygularına zarar verebilirim. Dini duygular bizim toplumumuzda sömürüye açık şeylerdir. Kesinlikle ve kesinlikle üzerlerine gitmiyorum. İstesem çeviririm ama.

Tablo 13: Toplumla Iliş̧ilerde Yaşanan Değişiklikler

\begin{tabular}{|l|l|l|}
\hline İnsanlarla ilişkiler & Kişi sayısı & Yüzde \% \\
\hline Toplumdan dışlananlar & 10 & 56 \\
\hline Toplumla barışanlar & 1 & 4 \\
\hline Değişiklik yok & 9 & 36 \\
\hline Diğer & 5 & 20 \\
\hline Toplam & $\mathbf{2 5}$ & $\mathbf{1 0 0 , 0}$ \\
\hline
\end{tabular}

Ateist veya deist olduktan sonra toplum içinde insanlarla ilişkilerinde ne tür değişiklikler yaşadığını sorduğumuz deneklerin \%40'ı toplumdan dışlandığını ve tepki aldığını, \%4'ü toplumla barıştığını söylemiştir. Toplumdan dışlandığını söyleyen 10 kişinin 6'sı ateist, 4'ü deisttir. \%36'sı herhangi bir değişiklik olmadığını dile getirirken \%20'si "diğer" seçeneği altında yer almıştır (5 kişi). Bu deneklerden ikisi sorun yaşayabileceği insanlara ateist olduğunu söylemediğini, ikisi artık insanlara insanî değerler çerçevesinde yaklaştığını, biri de çevresindeki insanların kendisi için üzüldüğünü söylemiştir.

Deist olduktan sonra dışlandığını ifade eden Ziya Bey karşı cinsle ilişkilerinde olumsuzluk yaşadığını belirtiyor:

Karşı cinsle ilişkilerimde deist olduğum için mesafe koyan, Müslüman olmazsan devam etmez şeklinde tepki veren oldu. İlişkilerimi olumsuz yönde etkilediği oldu. 


\section{İnsanların neden olumsuz yaklaştığını düşünüyorsunuz?}

Önyargı, korku, baskı, bir de dinin dogmatik kısmı. Yaşıyoruz işte tamam, vardır bir şey, bu da bizim için uygun bir din. Cevap arayışı içinde değiller, tatmin olmuşlar bir şeylerden, ekstra bir beklentisi yok hayattan. Kitaplarda verilen cevaplar onun için yeterli gelmiş.

Düşüncelerinden dolayı fiziksel şiddete varan muameleler gördüğünü söyleyen Nihat Bey ailesinin tutumunun sevindirici olduğunu aktarıyor:

Kürt kimliğime ateist kimliğim de eklenince insanlar tarafından dışlanıyorum. Ben defalarca kimliğim ve düşüncelerimden ötürü küfür ve hakarete, fiziksel şiddete varan olay yaşadım. Ailemin bu konudaki tutumu ise beni sevindiren bir düzeyde oldu. Kendileri, düşünceme daima saygılı oldular. Bazen küçük dini tartışmaların dışında, ki bunlar benim yüzümden çıkıyor, her şey iyi durumda.

Olmayan bir yaratıcıya ibadet etmeye çalıştığını ve bunun yanlış olduğunu belirten Hasan Bey ise ateizm düşüncesini seçtikten sonra insanlarla kaynaştı̆̆ını ifade ediyor:

Uzun bir dönemi dini yaşayarak geçirdiğim için arkadaş açlı̆ıım vardı, biraz da çevremde çok fazla insan yoktu. Ateist olduktan sonra sosyal aktivitelere zaman ayırma firsatım oldu. 0 sürede çok insanla kaynaştım. Bu insanlar Hıristiyan da oldu, ateist de oldu, imam da oldu. Sosyal açıdan güzel etkileri oldu. Kendimi iyi bir noktada bulduğumu söyleyebilirim.

Tablo 14: Toplumda Kendilerini Nasıl Hissediyorlar?

\begin{tabular}{|l|l|l|}
\hline Toplum içindeki durum & Kişi sayısı & Yüzde \% \\
\hline İnsanlar tepkili & 11 & 44 \\
\hline Rahat ve huzurlu hissedenler & 9 & 36 \\
\hline Herhangi bir değişiklik yok & 3 & 12 \\
\hline Bilgili ve farklı & 2 & 8 \\
\hline Toplam & $\mathbf{2 5}$ & $\mathbf{1 0 0 , 0}$ \\
\hline
\end{tabular}

Ateist veya deist olduktan sonra toplum içinde kendilerini nasıl hissettiğini sorduğumuz deneklerin \%44'ü insanların tepkili olduğunu ve kendilerini dışladığını, \%36'sı kendisini rahat ve huzurlu hissettiğini, \%12'si hissiyatında herhangi bir değişiklik olmadığını, Müslümanken olduğu gibi hissettiğini, \%8'i topluma göre kendisini bilgili ve farklı gördüğünü ifade etmiştir.

Dışlanmanın yaşadığı yere göre değiştiğini söyleyen Doğan Bey bir örnekle cevap veriyor:

Yaşadığım yer olan Antakya'da görüşümden dolayı dışlayan kimseye rastlamadım. Burada bayağı dışlama oluyor... Belki uç örnek olacak ama yaşadığım için söylüyorum, çocuklar aynı masada birbirlerinin annelerine küfür ederken gülerek karşıllyorlar, ancak "Ben ateistim." deyince "Ne demek ateistsin!" diye tepki gösteriyorlar.

Ozan Bey (ateist) de bulunduğu topluma göre rahatlık durumunun değiştiğini söylüyor:

Erzurum'da okudum ben, Ramazan ayında Erzurum'da sigara içtiğim için öldürülebilirim. Çankırıııyım, gerçek anlamda çok yobaz diye tarif edebileceğim bir yer. Çankırı'da Ramazan ayında, otogarda sigara içiyor diye şehre yeni atanan kaymakamı dövdüler. Kaymakam görev yerine ulaşamadan bırakıp gitti. Toplumun bu durumu, bizim toplumdan uzaklaşmamıza sebep oluyor. Ben sosyalist bir insanım, amacım, hedefim sosyalist bir devrim gerçekleştirmek, bunun için insanlarla etkileşime girmek zorundayım. Insanların karşısına çıktığım zaman ateist kimliğimle, hiçbir zaman çıkamıyorum, biraz tiyatrocu gibi olabiliyorum 
diyebilirim. Karşımdaki insan nasılsa biraz o şekilde davranıyorum. Sokakta yürürken, bir şeye sevindiğim zaman kız arkadaşıma sarılıp öpemiyorum. Bu durum beni biraz sıkışmış hissettiriyor. Rock konserinde kendimi daha özgür hissederken yaşadığım memlekette daha bunalmış, sıkışmış hissediyorum.

Hayatı boyunca dinle ilgilenmediğini ifade eden Volkan Bey (ateist), eskiye oranla daha iyi hissettiğini söylüyor: "Eskiden kafamda bir bulanıklık vardı, şimdi yok. Şimdi insanlar üzerinde daha iyi gözlem yapabiliyorum kendi açımdan. Çünkü kafam rahat."

Nihat Bey ateist olduğu için rahat hissettiğini, kimsenin dini kullanarak kendisini sömüremediğini belirtiyor: "Bu bir politikacı da olabilir, bir cemaat abisi/ablası da ya da basit bir esnaf da olabilir. Böylelikle fikirlerimi daha realist bir alanda, sezgici ve mistik bir havanın aksine daha makul, mantık ekseninde ürettiğimi düşünüyorum."

Sinem Hanım (deist) bakış açısının değiştiğini ve kendisini bilgili hissettiğini belirtiyor:

Her şeyi ben biliyorum, siz hiçbir şey bilmiyorsunuz. Bir yalana inandıklarını düşünüyorum. İnsanlara bakış açım değişti. Mesela kötü bir insanla karşılaştığımda ikimizi yaratan varlık aynı olamaz. Benim kimseye zararım yokken toplumda birçok insanın birbirine zararı var. Dinî inancın dünyada savaşlara neden olduğunu düşünüyorum. Bu yüzden insanların kötülüğünü inanç sistemlerine bağlıyorum. Yanlış inanç sistemlerine diyelim daha doğrusu...

Sonuç olarak deneklerin yarısına yakın bir kısmı bulunduğu ortama ve topluma göre tepki alma durumunun değiştiğini belirtirken, \%36'ık kesim ise sorgulama evresini geçip düşüncelerini netleştirdikten sonra rahat ve huzurlu hissettiğini belirtmiştir.

Tablo 15: Ateizm veya Deizm İnancını Gizleme

\begin{tabular}{|l|l|l|}
\hline İnancı gizleme durumu & Kişi sayısı & Yüzde \% \\
\hline Evet & 22 & 88 \\
\hline Hayır & 3 & 12 \\
\hline Toplam & $\mathbf{2 5}$ & $\mathbf{1 0 0 , 0}$ \\
\hline
\end{tabular}

Tabloda görüldüğü üzere deneklerin $\% 88^{\prime} \mathrm{i}$ (13 ateist, 9 deist) ateizm veya deizm inancını gizlerken, \%12'si ise her ortamda açıkça dile getirdiğini belirtmektedir.

Ateizm veya deizm düşüncesini gizleme durumu deneklerin bulunduğu ortama ve duruma göre değişim göstermektedir. Tepki, dışlanma ve hakaret görecekleri ortamda ateist veya deist kimliklerini gizlerken, hoşgörülü ve anlayışlı bir ortamda düşüncelerini belirtmekten çekinmemektedirler.

Aysel Hanım (deist), düşüncesini gizleme konusunda şöyle söylüyor: "Her alanda kendimi açıkça ifade edemiyorum. Saklamıyorum, ama konuşmamam gereken durumlar oluyor. Kendimi rahat hissetmediğim ortamlarda bu konu hakkında konuşmuyorum."

Herkesin iyi yaklaşmayacağını düşünen Can Bey (ateist) de ortama göre düşüncesini gizliyor:

Mesela bunu bir sınıfta anlatmamı istesen ben kabul etmem. Çünkü orada iyi niyetli olduğu kadar kötü niyetli insanlar da var. Yargılayacaklarını hatta daha da ileriye gideceklerini düşünüyorum. Çok var öyle insanlar, Ramazan'da yabancı bir adamın alkol içmesine bile karışanlar var yani. Aynı şekilde o adama saldıranlar falan, neden burada olmasın? Onun için toplum içinde konuşmak istemem.

Ziya Bey (deist), "Öleceğimi bilsem söylerim." derken, durumunu herkese açık açık beyan ettiğini dile getiren Aslan Bey (ateist) de herhangi bir çekincesinin olmadığını belirtiyor: 
Ben bu şekildeyim, isteyen gelir istemeyen gelmez. İsteyenle de mülakat yapabilirim, hiçbir sıkıntı yok.

\section{Tepki aldığınız durumlar oluyor mu?}

Bizi bir şeylerin yokluğuyla terbiye etmeye çalışıyorlar, paramızı vermeyiz, kızımızı vermeyiz. Paraları da kendilerinin olsun, eğer paraları helalse.

Tablo 16: Ateizm veya Deizmi Tercih ettikten Sonra Din Tebliğinde Bulunanların Olup Olmaması

\begin{tabular}{|l|l|l|}
\hline İslam'ı tebliğ edenler & Kişi sayısı & Yüzde \% \\
\hline Evet & 19 & 76 \\
\hline Hayır & 6 & 24 \\
\hline Toplam & $\mathbf{2 5}$ & $\mathbf{1 0 0 , 0}$ \\
\hline
\end{tabular}

Çalışmamıza katılan deneklerin \%76'sı ateizm veya deizmi tercih ettikten sonra kendilerine i̇slam dininin tebliğ edildiğini ifade ederken \%24'üne ise herhangi bir tebliğde bulunulmamıştır.

Ateist olduktan sonra din davetinde bulunanların çok olduğunu dile getiren Ozan Bey, anlatılanların kendisini etkilemediğini ifade ediyor:

Ben Kur'an-ı Kerim'i reddettiğim için ya da Allah'ın adil olmadığını düşündüğüm için ateist değilim. Aslına bakarsan ben ateist de değilim. Biraz felsefî yaklaşım olacak, ama bana göre Tanrı́nın varlığııı reddetmek demek, Tanrı'nın varlığını bir şekilde kabul etmek demek. Materyalistim, ruhanî olan herhangi bir şeye inanmıyorum. Henüz açıklanmasa bile, her şeyin bilimle açıklanabileceğine inanıyorum. Ben bunları söylediğim zaman karşımdaki insan da çaresiz kalıyor, benim için kaçış noktası diyebilirim.

Volkan Bey (ateist)'i İslam'a davet eden de çok olmuş: "Enes diye bir arkadaşım vardı, iki sene cumaya götürmeye çalıştı, ama ben pek yanaşmadım. 'Gel ben sana iki bira ısmarlayayım.' diyordum." Doğan Bey (ateist), "Ya dönersin ya da öldürürüz." diyenlerin bile olduğunu söylüyor.

Deneklere İslamiyet'i terk edip ateist veya deist olduktan sonra ailesinden, akrabalarından ve arkadaş çevresinden İslamiyet'i anlatanlar, tebliğ edenler olmuştur. Deneklerin ifadelerinden anlaşıldığı üzere, İslam'ı tebliğ edenlerin dinî bilgi düzeyi, deneklere karşı anlayışı ve hoşgörüsü, karşılıklı tartışma ortamı oluşturmuştur. Fakat İslam'ı tebliğ edenlerin genellikle bilgisiz ve anlayışsız olması, deneklerin bu insanlara karşı olumsuz tavır takınmalarına sebebiyet vermiştir.

Tablo 17: Ahlakî Değişiklik Yaşayıp Yaşamama

\begin{tabular}{|l|l|l|}
\hline Ahlakî değişiklik & Kişi sayısı & Yüzde \% \\
\hline Evet & 7 & 28 \\
\hline Hayır & 18 & 72 \\
\hline Toplam & $\mathbf{2 5}$ & $\mathbf{1 0 0 , 0}$ \\
\hline
\end{tabular}

Örneklemde yer alan deneklere, ateist veya deist olduktan sonra ahlakî anlamda değişiklik yaşayıp yaşamadıkları sorulmuştur. Deneklerin \%28'i ahlakî bir değişiklikten bahsederken, \%72'si değişim olmadığını belirtmiştir.

Değişiklik yaşadığını belirten Ümit Bey (ateist), artık karşııı beklemeden iyilik yaptığını anlatıyor: "Kendimi daha etik buldum. Müslümanken bu kadar etik değildim. Sıkıntı yaşayan bir insana yardım etmem, hiçbir 
karşılık beklemeden bunu yapmam beni mutlu ediyor." Aykut Bey (ateist) de eylemlerini sevap için değil, iyilik için yapmaya başladığını belirtiyor: "Karşııı beklemeden iyilik yapmaya başladım." diyor.

Sinem Hanım daha güzel ve temiz düşünmeye başladığını söylüyor: "Deist olduktan sonra kendimi otoriteden kurtardığım için eylemlerim daha özgür oldu... Çünkü bir yerde yanmayacağımı biliyorum. Huzurlu hissettiğimi söyleyebilirim, çünkü yanlış bir şey yapmıyorum."

Değişiklik yaşamadığını belirten Aslan Bey (ateist), "Hayır, hala aynı şeyler. Hatta Müslümanların çoğu dışladığı şeye rahatıkla bakmaya başladım. Lezbiyenler, gayler, transseksüeller bunların hepsine kucaklayan tavırla yaklaşıyorum." demektedir.

Sonuç olarak ahlakî anlamda değişiklik yaşadığını söyleyen denekler, daha önce sevap-günah çerçevesinde düşünülen iyiliğin karşılık beklenerek gerçekleştirildiğini, bunun etik olmadığını, ancak ateist/deist olduktan sonra kendi ahlak anlayışlarını oluşturarak karşııksız iyilik yapmaya ve daha etik davranmaya çalıştıklarını vurgulamışlardır.

Tablo 18: Ateizm veya Deizmde Kafa Karışıklığına Neden Olan Durumlar

\begin{tabular}{|l|l|l|}
\hline Kafa karışıklığı & Kişi sayısı & Yüzde \% \\
\hline Evet & 16 & 64 \\
\hline Hayır & 9 & 36 \\
\hline Toplam & $\mathbf{2 5}$ & $\mathbf{1 0 0 , 0}$ \\
\hline
\end{tabular}

Deneklerin \%64'ü (10 ateist, 6 deist) ateist veya deist olduktan sonra kafa karışıkığına neden olan durumlarla karşılaştığını ifade etmiş, \%36'sı (6 ateist, 3 deist) ise zihnini kurcalayan herhangi bir durumun olmadığını belirtmiştir.

Kafa karışıkığı yaşayan deneklerden Volkan Bey (ateist), şunları anlatıyor: "Oluyor, dört sene falan antidepresan içtim ben. Hani kafamıza kazınmış bir şeytan figürü vardır. Çok rüyalar gördüm, ama sabah kalktığımda hiçbir etkisi olmazdı. Gülerek kalkardım bazen."

Uğur Bey (deist), kafa karışıklığına neden olan tek durumun ölümden sonrası olduğunu vurguluyor:

Kafa karışıkığına neden olan tek durum şu: Bu hayatta varım, şu an etrafı görüyorum, duyuyorum. Öldükten sonra bana ne olacak? Tek kafa karışıklı̆ım şu an bu. Benim görüşüme göre öldükten sonra simsiyah bir şey var. Ölümden sonra hayatın olduğuna inanmıyorum. Ama bunu açıklayamıyorum kendime. Bir de şu var, evrenin yaratııı̧ı Big-Bang teorisiyle anlatılıyor. Peki Big-Bang'den önce ne vardı? Yine simsiyah bir şey canlanıyor kafamda.

Deizm inancı gereği Tanrı́nın bu dünyadan elini kolunu çekmiş olması gerekirken Dilan Hanım (deist), bazen bu düşüncenin sınırlarını aştığını ifade ediyor: "Sadece şunu merak ediyorum, müdahalesi var mıdır, yok mudur?... Deizmi tamamen kabul ediyorum, ama bazen düşünmüyor değilim, ilahî adalet dediğimiz şey var."

Ebru Hanım (ateist), manevî anlamda huzursuz hissettiğini belirtiyor: "Çevremde çok fazla dini yaşayan insan var, net bir sıkıntı olmadı, ama manevî anlamda huzursuz hissediyorsun kısmen. 'Neden net bir şekilde ayrışıyoruz?' kısmı rahatsız ediyor beni ve sorgulamaya itiyor."

Dedesinin imam olduğunu vurgulayan Aydın Bey (ateist), agnostisizm ile ateizm arasında gidip geldiğini aktarıyor: "Fakat ateizm düşüncesi daha ağır basıyor. Bazen Tanrı'nın var olabilme düşüncesi oluyor. Tek kafa karışıkığı bu. Ama kesinlikle Müslümanlık veya diğer dinlerle ilgili bir kafa karışıklı̆ı olmadı." 
Esra Hanım (deist)'ın düşüncesi ise Aydın Bey (ateist)'in düşüncesiyle taban tabana zıtlık gösteriyor: "Kutsal bir gücü, yaratıcıуı kabul ediyorum, ama bazen 'Acaba var mıdır?' diye düşünüyorum. Biraz ateizme kayıyor gibi oluyorum."

Deneklerin verdiği cevaplar genel olarak incelendiğinde ateistlerin daha çok "Acaba Tanrı olabilir mi?" konusu çerçevesinde; deist olanların ise "Acaba Tanrı'nın yeryüzüne müdahalesi var mıdır?" ya da "Ya Tanrı yoksa" gibi sorular etrafında zihin bulanıklığı yaşadığını görmekteyiz.

Bu tür durumların her zaman var olduğunu ifade eden Hamdi Bey (deist), şöyle sorguluyor: "Hep aynı şeyi düşündüm. 'Bir varlık nasıl yoktan var olabilir?' sorusu hep aklımdaydı, hala daha aklımda. Deizm bunu değiştirmedi mesela."

Kafa karışıklığına neden olan herhangi bir durum olmadığını söyleyen denekler, genel olarak ateist veya deist olmadan önce kafa karışıklı̆ı yaşarken, ateist veya deist olduktan sonra düşüncelerinin netleştiğini, kafa karıştıııcı durumların ortadan kalktığını belirtmiştir. Ümit Bey de ateist olmadan önce kafasının karışık olduğunu izah ediyor:

Materyalist bir insanım, evrime inanıyorum. Bütün canlıların, doğanın evrimle... meydana geldiğini düşünüyorum... Öznel düşünceme göre Âdem ile Havva yok... Aradaki evrimsel bağları doldurabiliyorsak bu teori yakında kanun olacak. Dünyanın şu an \%70'i inançlı, bir yaratıcıya inanıyor, evrime inanmıyor. Böyle birşeyin ortaya çıkması belki de bütün inançları, toplum yapısını altüst edecek... Evrim teorisine inandığım için aklım daha net. Ben bilime inanıyorum, bilim şu anda evrim teorisini kanıtlıyor. Körü körüne inanmıyorum, altyapısını dolduruyorum...

Tablo 19: Ateist veya Deist Olduktan Sonra İslam Hakkında Yeni Eleştiriler

\begin{tabular}{|l|l|l|}
\hline İslam hakkında eleştiri & Kişi sayısı & Yüzde \% \\
\hline Evet & 23 & 92 \\
\hline Hayır & 2 & 8 \\
\hline Toplam & $\mathbf{2 5}$ & $\mathbf{1 0 0 , 0}$ \\
\hline
\end{tabular}

Araştırmamıza katılan deneklerin tamamına yakınının (\%92) ateist veya deist olduktan sonra İslam dinine yönelik yeni eleştirileri olmuştur.

Deist olduktan sonra İslam hakkında yeni eleştirisi olduğunu söyleyen Ziya Bey, ayetlerin Tanrı́nın sözü olamayacağını belirtiyor:

En basitinden ilk aklıma gelen Ahzap suresi 53. ayet. ${ }^{32}$ Kaba tabiriyle söylemeye çalışayım. "Peygamberin evine girdiğiniz zaman çok kalmayın, yemeğinizi yiyin gidin, o sizden sıkılıyor, ama size söyleyemiyor." Bunu bir Tanrı'nın söylediğine inanmıyorum. En büyük eleştirim bu noktada. Oruç diye bir kavram getiriyorsun. Kutuplarda altı ay güneş batmıyor. $O$ insanlar nasıl oruç tutuyor? Namazın nasıl kılındığı Kur'an'da yazmıyor. Peygambere bakarak insanlar namaz kılma şekli oluşturmuşlar.

\footnotetext{
32 Ziya Bey'in bahsettiği ayetin tam metni şöyledir: "Ey iman edenler! Peygamberin evlerine, izinsiz ve yemek vakti davetsiz olarak girmeyin; yemek için çağırıldığınızda da davet vaktinden önce gidip orada beklemeyin. Yemeğe çağırıldığınız zaman girin; yediğinizde de birbirinizle sohbete dalmadan hemen dağılın. Bu hareketiniz Peygamber'i rahatsız ediyor; ancak o size bunu söylemekten sıkılıyor. Allah ise hakkı açıklamaktan çekinmez. Peygamber hanımlarından bir şey isteyeceğiniz zaman da onu perde arkasından isteyin. Sizin kalbiniz için de onların kalpleri için de böylesi daha nezihtir. Peygamberi üzmek de onun ölümünden sonra hanımlarını nikahlamak da size ebediyen yasaklanmıştır. Bunları yapmanız Allah katında büyük bir günahtır." (Ahzab, 33/53)
} 
Ebru Hanım (ateist), İslamiyetin kadını yücelttiğine dair söylemlerin kendisini tatmin etmediğini dile getiriyor:

En başında i̇slam'ın kadına bakışı geliyor. Bana çok fazla sorgulatmıştı. Diğer dinlere baktığında da aynı direktiflerin verildiğini görüyorsun. Ayetlere bakarken birine değil tamamına bakın diyorlar, hepsine baktım. Caydırıcı bir şey göremedim. Nisa suresi bilhassa 34. ayet ${ }^{33}$ kadınlarınız diyor size herhangi bir nedenden dolayı itaat etmezlerse önce onları uyarın, aynı şeyleri yapmaya devam ederlerse onları yataklarında yalnız bırakın, hala devam ederlerse usulca dövün, usulca demiş, ama dövün demiş sonunda. Bunun bana açıklaması getirilemez. Bu ayetin masum gösterilecek hiçbir tarafı yok bence. Kaldı ki, İslamiyet'ten sonra kadının yerinin ve öneminin arttığı söylenir. Ben onların boş söylemler olduğunu düşünüyorum. Hiçbir şekilde İslamiyet'in kadını yücelttiğine dair söylemler tatmin edici gelmiyor.

Ateist olan IIlknur Hanım, Kur’an-ı Kerim'in indirildiği döneme hitap ettiğini söylüyor:

En basitinden "Zina yanlıştır." deniyor, çünkü o dönemde doğum kontrolü denen bir şey yoktu. İstenmeyen çocukların doğması hoş karşılanmayacaktır tabi ki. Oysa şu an bilinçli her insan istediği kişiyle rahatlıkta birlikte olabiliyor, yani sadece o tarihle ilgili bir durum olduğunu düşünüyorum. Veya kutuplardan hiç bahsedilmiyor, Kuzey kutbunda güneş altı ay boyunca hiç batmaz, orucunu nasıl açarlar? hiç yazılmamış mesela. Nereden bilsin o dönem onu yazan adam, ama Allah'ın bilmesi lazımdı oysa. Cinsel ilişkinin detaylarını yazacaklarına bu gibi şeylere yer verebilirlerdi. Kadını çarşafa sokup, eve kapatmadan, erkeklerle eşit olduğunu, toplumsal barış, hatta evrensel barış gibi şeylere yer verilseydi daha mantıklı olabilirdi.

Dilan Hanım (deist) ise dinin korkudan beslendiğini öne çıkarıyor:

İnsanların belirli bir dinde sadece cehennem, günah, sevap altında birleştiğini görünce bunu saçma bulmaya başladım. Din kesinlikle insanları ödül-ceza sistemine tabi tutuyor. Ben o kadar övülen, merhametli bir yaratıcının kesinlikle yaratmış olduğu kulların üstünde baskı kurmasını, bu kadar bize ihtiyaç duyduğunu düşünmüyorum. Din de Tanrı bize muhtaçmış gibi davranıyor, ben pek hoşlanmıyorum bu tutumdan, bana saçma geliyor.

Sinem Hanım (deist), Tanrı́nın dünyaya müdahalesi konusunda eleştirilerinin olduğundan bahsediyor:

Allah konusunda eleştirilerim oldu. Allah'a yönelik sorularım oldu. İnsanlar neden ölüyor? Çocuklar neden ölüyor? Benim çocuğum olsa, biri gözümün önünde çocuğuma kötülük yapsa, ben buna müdahale ederim. Bizi yaratan varlık, bizi her şeyden daha çok seven bir varlıktır. Neden müdahalesi yok? Bu bir sınav olamaz. 5 yaşında bir çocuğun sınavdan geçebileceğine inanmıyorum ve onun ailesinin 5 yaşındaki çocukla sınav olma ihtimalini düşünmek istemiyorum. Toplumda her şey kaos içinde, neden müdahale etmiyorsun ki? Ya da be sana dua ediyorum, her şeyin güzel olmasını diliyorum, neden inandığını söyleyen insanlar dualarına karşılık aldığını söylerken benim dualarıma karşılık vermiyorsun? Bir yerde

\footnotetext{
${ }^{33}$ Ebru Hanım'ın bahsettiği ayetin tam metni şöyledir: "Allah'ın insanların bir kısmını diğerlerine üstün kılmasına bağlı olarak aile içinde yüklendikleri malî sorumluluklar sebebiyle erkekler, kadınların koruyup kollayıcısı durumundadır. Dolayısıyla saliha kadınlar itaatkardırlar. Allah'ın, onların kocaları üzerindeki haklarını korumasına karşılık, hanımlar da kocalarının bulunmadığı zamanlarda kendilerini, onların mallarını ve çocuklarını korurlar. Size karşı geleceklerinden endişe ettiğiniz hanımlarınıza önce nasihat edin, fayda vermezse yatakta yalnız bırakın, bu da sonuç vermezse onları hafif̧̧e dövün. Size itaat ederlerse artık onlara haksızlık etmek için herhangi bir bahane aramayın. Çünkü Allah çok yücedir, büyüktür." (Nisa, 4/34)
} 
varsan neden orada bana kendini göstermiyorsun? Bunu şöyle düşün: Evde oturuyorsun, bir hafta kapının çalmasını bekliyorsun, ama o kapı çalmıyor. Bir ay bekliyorsun, o kapı çalmıyor. Bir yıl bekliyorsun, o kapı hala çalmıyor. Artık zihninde şunu düşünüyorsun "O kapı hiçbir zaman çalmayacak."... Din olarak da şunu sorguluyorum aslında "Söyleyeceklerin bu kadar mıydı ki Hz. Muhammed öldü,... her şeyi söylemiş miydin, her şeyi belirtmiş miydin, neden bir peygamberlik sistemi oluşmadı daha sonra?" Allah'ın kelamının bu kadar az olabilme ihtimalini düşünmüyorum. Bize bir mesaj göndermişse eğer ya da gönderecekse şimdi de devam etmesi lazım. İnsanlara şunu söylemesi gerekir "Ben sizi bir yerlerden görüyorum, kendinize gelin." demesi lazım. Bunu söylemediği için sorguluyorum haliyle.

Ümit Bey (ateist) de kadınlardan yola çıkarak sıralıyor eleştirilerini: "Birçok eleştirim oldu. Kadınların kapanması gerektiği, kadının toplumda... erkeğe göre biraz daha hizmetçi rolündeymiş gibi olması, kadın sadece çocuk yetiştirir gibi algının olması eleştirdiğim noktalardan..."

Aslan Bey (ateist), Kur'an-ı Kerim'in farklı yorumlara açık bir kitap olduğunu söylüyor ve kadın haklarına değiniyor:

Her okuyan kendine göre bir yorum çıkartmaya çalışıyor. ışiD de aynı kitabı okuyor, Adnan Oktar da aynı kitabı okuyor, farklı farklı şeyler çıkıyor. Mesela bir Nisa suresine baktığınızda kadınlara ne kadar haksızlık yapıldığını görüyorsunuz. O suredeki, ayetlerin yarısından fazlasının kadınlara hakaret olduğuna inanıyorum.

Nihat Bey (ateist) ise hac ibadetinin içinin boşaltılarak turistik bir faaliyete dönüştürüldüğünü, bu konuda sert eleştirileri olduğu için babasının hacca gitmediğini belirtmektedir. Ozan Bey (ateist)'in söyledikleri ise yaratıışla ilgili: “...Kadının yaratıışı benim için muammaydı, gülünç gelirdi. Neden böyle yazıldığını bilemeyeceğim, şüpheye düşeceğim için her zaman atlardım. Erkeğin kaburgasından yaratılmıștır falan..."

Şu net bir şekilde söylenebilir ki; kendisini ateist ya da deist olarak ifade edenlerin tamamına yakını, insan aklının içinden çıkamadığı dinî konulara tepki olarak ateist ya da deist olmuşlardır. ${ }^{34}$

Ayrıca deneklerin, dinin bizatihi kendisine değil de, dine mensup olanların söylem ve davranışlarına bakarak din hakkında karar verdiği de söylenebilir.

Tablo 20: Deneklerin Kendini Farklı Bir Kişi Gibi Hissedip Hissetmemesi

\begin{tabular}{|l|l|l|}
\hline Farklı bir kişi gibi hissetme & Kişi sayısı & Yüzde \% \\
\hline Düşünen, araştıran, soruşturan & 9 & 36 \\
\hline Özgür, ferah, olgun hisseden & 6 & 24 \\
\hline Hayır & 10 & 40 \\
\hline Toplam & $\mathbf{2 5}$ & $\mathbf{1 0 0 , 0}$ \\
\hline
\end{tabular}

Ateist veya deist olduktan sonra deneklerin \%36'sı kendisini düşünen, araştıran, soruşturan bir kişi gibi hisettiğini, \%24'ü özgür, ferah ve olgun hissettiğini, söylerken \%40'ı herhangi bir değişiklik olmadığını vurgulamıştır.

Uğur Bey (deist), dinden çıktıktan sonra bazı kısıtlamalardan kurtulduğunu, sorgulamaya başladığını, yani bilime yöneldiğini belirtiyor: "Yeni bir kişi olduğumu düşünüyorum. Sorgulayıcı bir kişi olduğum söylenebilir."

Ateist olduğunu ailesinden yalnızca ağabeyinin bildiğini söyleyen Can Bey de sorgulayıcı yanının geliştiğine vurgu yapıyor: "Daha çok araştırmayı öğrendiğimi söyleyebilirim. Aldığım bir bilgiyi direkt kabul etmek

\footnotetext{
${ }^{34}$ Dorman, "Modern Çağda Deizmin Popülerleşmesi ve Sebepleri", Diyanet Aylık Dergi, 2017 (320), s. 14.
} 
yerine tamam, doğrudur, eyvallah ama bir bakalım karşı düşünceden kim ne diyor? diye yaklaşmaya başladım olaylara. Sorgulayıcı yanım gelişsti."

Sinem Hanım deist olduktan sonra kendisini özel hissettiğinden bahsediyor:

Önceden Allah'a sığınıyordum... İnanılmaz derecede dua ediyordum, yalvarıyordum. Ama bu şundan kaynaklıydı, bir cehennem algısı, cehennem korkusu vardı. Sonradan şöyle düşündüm, "Eğer sen sadece cehennemde yanmamak için dua ediyorsan, ibadet ediyorsan iyi bir insan değilsin. Sen artık cehennemde yanmayacağını biliyorsun, o zaman artık eylemlerini iyilik, güzellik, eşitlik ve adalet üzerine kurmalısın. Kendi adalet sistemini oluşturmalısın." Kendi adalet sistemimi oluşturduktan sonra farklı bir kişi gibi hissettim. Adil ve özgür düşünmeye başladım, fakat bu korkudan değil.

Sinem Hanım'ın şımdi aktaracakları ise kafasının net olmadığını göstermektedir: "Allah'ın varlığına inanıyorum, ama sorguluyorum da. Çelişkideyim, bir yıl sonra ateist olabilirim. Bu çok rahat bir şey, deizmi kafamdan silebilirim. Çünkü kendini göstermiyor, bir mucizesi de yok, mucizesi olmuş olsaydı da inanmazdım."

Hayatı boyunca hiç oruç tutmadığını, sadece dedesi para verdiği için camiye gittiğini belirten Volkan Bey (ateist), artık kendisini özgür hissettiğini, düşünecek hiçbir şey kalmadığını ifade ediyor: "Kötü bir şey yapmak istiyorsam beni arkaya çekecek bir şey yok. O yüzden kafama esen şeyleri yapabiliyorum yani."

Müslümanken çevresindeki ateistleri her ne kadar içki sofralarında da olsa dine davet ettiğini belirten Ozan Bey (ateist) ise bir süre mutsuz hissettiğini fakat zamanla geçtiğini söylüyor: "inandığım şeylerin yalan olduğunu öğrenince bir depresyon dönemi geçirdim, depresyon dönemini atlatınca hiçbir sıkıntı olmadı."

Tablo 21: Tekrar Dine İnanma

\begin{tabular}{|l|l|l|}
\hline Tekrar inanma & Kişi sayısı & Yüzde \% \\
\hline Evet & 9 & 36 \\
\hline Hayır & 16 & 64 \\
\hline Toplam & $\mathbf{2 5}$ & $\mathbf{1 0 0 , 0}$ \\
\hline
\end{tabular}

Deneklere “Tekrar bir dine inanma ihtimaliniz var mı?" sorusu yöneltilmiş, \%36'sı ( 3 ateist, 6 deist) "evet" \%64'ü "hayır" şeklinde cevap vermiştir.

Ateist olduğunu söyleyen İsmet Bey, belki de bu çalışmanın en enteresan cevaplarından birini veriyor: "Bilmiyorum yani, Allah bilir diyelim. Gidişat onu göstermiyor, ama ilerleyen zamanlarda bir şey olursa olabilir yani."

Aslan Bey (ateist), tekrar bir dine inanmasının ancak şu şartlarda mümkün olduğunu dile getirmektedir: "Yeni bir din oluşur, çok mantıklı ve makul gelir, o zaman inanırım. Herhangi peygamberi olan bir din olsun, gökten indiği sanılan kitaplar der Atatürk. Böyle olursa yapamam."

Türkçülüğü benimsediğini söyleyen Ziya Bey (deist), tekrar bir dine inanma ihtimali ile ilgili sorduğumuz soruya tamamen Marksist bir düşünceyle cevap vermiştir:

Yok, kesinlikle yok. Dinlerin insanları zamanında bir çatı altına toplamak için, kolay yönetebilmek ve onlara bu dünyada kolaylıkla erişemeyecekleri bir şeyi vaat ederek tamamen algıyı bir yöne çekmek amacıyla kurulduğunu düşünüyorum. Düşünsene cennet vaat ediliyor sana. Bu dünyada hiçbir zaman erişemeyeceğin bir şey.

Uğur Bey (deist), bir dine inanması için somut bir şeyler olması gerektiğini söylüyor: 
Neden olmasın, yani şu an kesin bir şey yok. Bir şey kanıtlanırsa bilimsel açıdan, Tanrı varmış, din varmıs, öyle bir olay yaşanırsa yarın olabilir, on yıl sonra olabilir, hiç fark etmez. Kanıtlandığı anda görüşüm değişebilir. Ben bu deizme körü körüne bağlı bir insan değilim. Dinimi değiştirdikten sonra da hiçbir şeye körü körüne bağlanmamayı öğrendim. Benim için somut bir şeyler gerekiyor.

Can Bey (ateist), tekrar bir dine inanma konusunda açık kapı bıraktığını söylüyor: "Bu konuda kendimi kapatmadım. Kutsal kitaplarda olan mucizelerden birini gözle görmem lazım herhalde, böyle bir şey olması için. Ya da yanlış olduğunu düşündüğüm bir şeyin doğru çıkması."

Bir dine inanma ihtimalinin olduğunu söyleyen gerek ateist gerek deist deneklerin genel düşüncesi, dine ait herhangi bir mucizenin somut olarak yaşanması ve bilimsel açıdan ispatlanması noktasında birleşiyor. Bu veriler, bilimin ve ispatın denekler için hakikatin ölçüsü haline geldiğini göstermektedir.

Tablo 22: Ölüm ve Sonrası Hakkında Düşünce

\begin{tabular}{|l|l|l|}
\hline Ölüm ve sonrası & Kişi sayısı & Yüzde \% \\
\hline Sonsuz karanlık & 15 & 60 \\
\hline Fikrim yok & 6 & 24 \\
\hline Reenkarnasyon & 2 & 8 \\
\hline Diğer & 2 & 8 \\
\hline Toplam & $\mathbf{2 5}$ & $\mathbf{1 0 0 , 0}$ \\
\hline
\end{tabular}

Deneklerin \%60'ı (9 ateist, 6 deist) öldükten sonra bedenin çürüyüp toprağa karışacağını ve sonsuz bir karanlık olacağını, \%24'ü ( 5 ateist, 1 deist) ise bu konuda herhangi bir düşüncesinin olmadığını, \%8'i (1 ateist, 1 deist) ise reenkarnasyonla var olan enerjinin başka bir bedende devam edeceğini belirtmiştir. Reenkarnasyona inanan denekler ruh kavramına inanmamaktadır. Ruh kavramının yerine yaşam enerjisini koymuşlardır. \%8'lik (2 deist) bir grup "diğer" seçeneği içinde yer almıştır. Bu deneklerden biri tamamen yokluğun olmadığını, diğeri de dünyada yaşama devam edileceğini ifade etmiştir. Bu rakamlara göre ateist ve deist deneklerin ölüm sonrası hakkındaki düşünceleri birbirine oldukça yakındır.

Doğarken hiçbirşey hatırlamadığını, öldükten sonrasının da karanlık olacağına inanan Aslan Bey (ateist), kendisini insanlığa bağışlıyor:

Öldükten sonra beni ne yapsınlar? Kimi ateist der ki "Beni yaksınlar.", kimi der ki "Beni toprağa kavuşturun, başıma bir şey koymayın." Ben de diyorum ki, benim kadavralarımı alsınlar, insanlığa bağışlasınlar. Doktorlar bir şeyler öğrensin, benden sonra gelen insanlara bir şeyler katsın. Doktorların zaten en sevdiğim yanı o, Müslüman, Hıristiyan demeden herkesle ilgileniyorlar. Ben de kadavralarımı Müslüman, Hıristiyan demeden bütün insanlara bağışlıyorum.

Doğan Bey (ateist), ölümden sonra bir şeylerin olmasını temenni ediyor:

Ölümden sonrası için bir şeyin olmasını çok istiyorum. Umuyorum ölümden sonra bir şey vardır. Yüzleşemediğim, konuşamadığım, çok özlediğim insanlarla, benden önce göçüp gidenlerle belki orada buluşuruz diye. Ama asla ihtimal vermiyorum böyle bir şeye. Beden çürüyecek, bakteriler ayrıştıracak, toprak zenginleşecek, herhangi bir şey olmayacak.

Volkan Bey (ateist) de bu konunun kendisinde net olmadığını, ancak sevdiği insanları tekrar görmek istediğini belirtiyor.

Tolga Bey (ateist), cennet-cehennem kavramlarının var olmadığını, ancak başka bir şekilde oluşacağımızı düşünüyor. 
Esra Hanım (deist) reenkarnasyon düşüncesinin henüz çocukken başladığını dile getiriyor:

Küçükken bana çok benzeyen bir fotoğrafla karşılaşmıştım. Almanya'da bir sergide tam olarak benim aynım. Bir prensesmiş, ilk başta inanmamıştım, sonra tekrar fotoğraflar gönderildi, o zamanlar çok küçüktüm. O zamanlardan bu zamanlara sanki tekrardan hayat bulacakmışım gibi hissediyorum. Bedenimiz yok olsa bile ruhumuz devam edecekmiş gibi geliyor bana.

Dilan Hanım, ölümden sonrasına henüz cevap bulamadığını söylüyor: "Bu soruya henüz cevap bulmuş değilim. Eğer gelmeden önce bir yerdeysek öldükten sonra da oraya gideceğiz. Ama hiçbir yere ait değilsek sadece anne bedeninde var olan canlılarsak nasıl doğumdan öncesini hatırlamıyorsak ölümden sonrasını da hatırlamayacă̆ız. Kesinleşmiş bir düşüncem yok."

Seda Hanım (deist)'ın söyledikleri de Dilan Hanım (deist)'ın anlattıklarına benzemektedir: "Ölümden sonra başka bir hayat olduğuna (cennet-cehennem kavramına) inanmıyorum. Daha doğrusu ölümden sonra ne olduğu veya ne olacağı hakkında kimse bir iddiada bulunamaz."

Ümit Bey (ateist)'in ölüm ve sonrasıyla ilgili görüşleri şöyledir: "Bilmiyorum, ama yıldız tozu olacağız hepimiz. Cehenneme gideceğimi düşünmüyorum. Hiçbir ateistin olmadığı gibi benim de fikrim yok. Eğer ki bir hesap vereceksek bu hesap verme gününden de korkmuyorum..."

Hamdi Bey (deist) ise korktuğunu dile getiriyor: "Sonsuz bir rüya olduğunu düşünüyorum. Çok büyük bir karanlık, o yüzden çok korkuyorum açıkçası ölmekten."

\section{Semavî Kitaplar Hakkındaki Fikirler}

Deneklere "Vahiy yoluyla gönderilen kutsal kitaplar hakkındaki düşünceniz nedir?” diye sorulmuş ve şu cevaplar alınmıştır.

Aykut Bey (ateist), genelde vahiy kavramına inanmadığını, kitapların insanlar tarafından yazıldığını söylemektedir.

"Keşke herkes inancını bilse ve ona göre davransa." diyen Ümit Bey (ateist), kitapların vahiy yoluyla gönderilmediğini düşünüyor:

Düşünseydim inançlı olurdum. Kitapların çıkış noktasında da toplumun düzenini sağlamak için oluştuğunu savunuyorum. Dinler devletse eğer kitaplar da bu dinlerin anayasasıdır. Kitapların içindeki ucu açık kelimeler yüzünden, farklı yorumlamalardan dolayı mezhepler oluşuyor. Mevlana'nın kitabı yorumlamasıyla, ışiD'in kitabı yorumlaması çok farklı. ikisi de aynı kitabı okuyor, hiç değiştirilmemiş. Ucu açık kelimeler olarak düşünüyorum kitapları.

Uğur Bey (deist), kitapların suç oranını azalttı̆̆ını söylüyor:

Kutsal kitaplar benim görüşümce çok zeki insanlar tarafından toplumu, insanlığı belli bir yola, iyiliğe sevk etmek için yazıımış şeyler. Şu an bir din olmadığını varsayarsak etrafta suç oranı artar, insanlar bir şey yapacağı zaman bunun günah olduğunu, öldükten sonra sorgulanmayı düşünüyor. Bunları düşünüp o şeyi yapmıyorlar. Çok zeki insanların çıktığını, Muhammed, İsa olur, bu kitabı yazdıklarını ve tek başlarına olmasa bile çevresindeki insanlarla yazdıklarını ve insanları belli bir yola sevk etmek için, kendi uğruna savaştırmak için bu dinlerin yaratıldığını düşünüyorum. Bir insana en kolay empoze edilebilecek şey ölüm korkusudur. Herkes öldükten sonra kendi varlığının, ruhunun devam etmesini ister. Zeki bir varlığın görüşü bu.

Deist deneklerimizden Dilan Hanım, dinin hiçbir zaman mantığına uymadığını, kitaplarıysa toplumun düzenleyicisi olarak gördüğünü ifade ediyor: 
Ben yüce Tanrı́nın dinini anlatmak için böyle bir yol seçtiğine inanmıyorum, bunları bir kitapla kısıtlayacağını düşünmüyorum. Muhammed'i, yaşadığı dönemde toplum düzenleyicisi olarak görüyorum ben açıkçası, bu da bir kitapta toplanmış, dönemin koşullarından etkilenmiş ve bunun adı din olmuş. O yaşasa şaşıırdı bence kitabının bu kadar ünlü olduğuna.

Can Bey (ateist) kitapların insan ürünü olduğunu düşünüyor:

Kitapların vahiy yoluyla gönderildiğini değil de o dönemde gerçekten zeki insanlar, toplumu tanıyan insanlar tarafından yazıldığını düşünüyorum.

\section{Peki, zeki dediğiniz insanlar neden bu kitapları yazma gereği hissetti?}

Toplumu kontrol altına almak için. Din toplumu kontrol altına almak için çok iyi bir araçtır. Öyle olduğunu düşünüyorum.

illknur Hanım (ateist), "Vahiy yoluyla mı gönderildiler, buna emin miyiz? Bana hikâye gibi geliyor." demektedir.

Ziya Bey (deist), kutsal kitapların kendisine komik geldiğinden bahsediyor:

Tanrı́nın bir insanla konuşacağını düşünmüyorum. Ya da "Neden o, neden ben ya da bir başkası değil? Neden bir kişiyi aracı yapıyor?" Bugün bile bir başbakan varken dört tane başbakan yardımcısı var. Danışmanları saymıyorum bile. Tanrı'nın bir kişiyi seçip onu aracı yapması, ona söylediği şeyleri başkasının duymaması saçma geliyor bana.

Hasan Bey (ateist), "Farkındaysanız eğer, inen dört kitaptan üçü cahil Arap topluluklarına inen kitaplar..." şeklinde cevaplamaktadır soruyu.

Öğretmeni kendisine "Namaz nasıl kılınır?” ödevini verdikten sonra araştırmaya başlayan, ardından annebabasına müracaat eden Yeşim Hanım (deist) "Siz kılıyor musunuz?" sorusuna "Biz namaz kılmıyoruz." cevabını aldıktan sonra birşeylerin farkına vardığını belirtiyor: "Bir dağda kutsal kitabın insana fısıldanarak gelmesi bana uçuk geliyor... Mesela Tanrı insanı bir deriden yaratmış. Bizim elbisemiz deri. Neden kitapta ayak bileğimden başlayıp saçım görünmeyecek kadar kapanmamı söylüyor. Beni bu deriyle yaratmış, ama bana neden kapanmamı söylüyor. Bu bana çok saçma geliyor."

\section{Ateistlerin Yaratıcıya İlişkin Düşünceleri}

Araştırmamıza katılan 15 ateist deneğe, daha önce bir yaratıcıya inanmaları sebebiyle "Yaratıcı ile ilgili sizi şüpheye düşüren konular hakkında bilgi verir misiniz?" şeklinde bir soru sorulmuştur. Deneklerin bu soruya verdiği cevaplar çok çeşitlilik arzetmektedir.

Aydın Bey (ateist) Tanrı'yı, insanları kendisine taptırmak isteyen bir egoist olarak nitelendirmektedir: "Tapmayanları bin bir türlü yolla cezalandıracağını söyleyen bir sadist, eşitlik, barış gibi kavramları olmayan, savaşı farz kılan ırkçı, homofobik. Cennette yalnızca erkeklere huri vadeden, kadınları dövmeyi kutsal kitabında belirten cinsiyetçi vs. özelliklerinden dolayı yaratıcıya inanmayı bıraktım."

Can Bey (ateist), Kuran'da yazılanların yaratıcıyla alakası olmadığını düşünüyor:

Yaratıcı varsa eğer, öyle kitapların yazılmasına izin vermeyeceğini düşünüyorum. "Ben bir yaratıcı olsaydım”, genelde böyle düşüncelerle ateizme yöneldim. Gücüm varsa, bir toplumu veya bir çocuğu açlıktan kurtarabileceksem, bir tecavüzü engelleyebileceksem, onu yapardım. Kötülüğü bırakmazdım, sonuçta benim elimde insanlar niye iyi yaşamasın ki, niye kötü yaşasın ki? 
Diyalektik materyalizme, dolayısıyla maddeye inandığını dile getiren Ebru Hanım (ateist), bunun maddeye tapmak ya da herşeyi parasal olarak düşünmek anlamına gelmediğini belirtiyor: "Diyalektik materyalizm okuyunca biraz da şekilleniyor, somut düşünüyorsun ister istemez. Varlığını bilmediğim, görmediğim, şahitlik etmediğim, net bir dayanağı olduğunu düşünmediğim için reddediyorum."

Nihat Bey (ateist), tatmin olmadığı konuyu şu şekilde izah ediyor:

"Kün feyekûn" ve "Hiçbir şey yoktan var olmaz." arasındaki tuhaflık. Bilimsel olarak hiçbir şey yok olmaz. Doğa içinde farklı düzeylerde yok olduğunu düşündüğümüz şeyler bir şekilde varlığını devam ettirir. Dünyanın oluşumu, bir mucize olarak görünüyor dinlerce, ama bilim buna "Big-Bang" diyor. Kafamı karıştıran mesele budur. İslam düşünürlerinin bu konudaki çalışmaları beni hayrete düşürdü desem yanılmam. Buna tanrısal öz de diyen var, maddenin özü de...

Ozan Bey (ateist), insanların imtihan dünyasında olmasıyla sonuçları bilinen bir oyunu oynamak arasında fark olmadığını dile getiriyor:

Ben bir yaratıcı olsam insanlar bana tapınsın, namaz kılsın, ibadet etsin, onları denemek istemem... Sonuçlarını bildiğim bir oyunu oynamak istemem. Bilgisayar oyunu gibi düşünelim. Oyun karakterini istediğim yere gönderdim ve ne olacağını merak etmem. O karakter oraya gidecek, ona istediğin kadar irade ver, onu sen yaratmışın, sen o tuşa bastın diye o var. Karakterin ne yapacağını merak etmem, izlerim, "Ne güzel şey yaptım." diye düşünürüm. Insanlar günde bana beş vakit ibadet etsin ve benim varlığımı kabul etsinler istemem. Çocukluğumdan beri böyle düşündüm. O yüzden hep namaz kılmayı reddettim. Kudretinden sual olunmayan yaratıcı neden kendisine tapınılmasını istesin ki? Bu bana hep ironik gelmiştir. Bu söylediklerim Müslümanlık içindi, diğer dinler hepten fiyasko. Hıristiyanlık için düşünelim, bir Tanrı var ve bu Tanrı'nın bir de oğlu var. Nerede ilahilik? Zeus'un da çocukları var.

Tolga Bey (ateist)'in çözemediği konu yaratıılı̧la alakalı: "Insanların meydana gelmesi, din ile bilimin çatışması, insanların soyunun maymunlardan mı geldiği yoksa bir yaratıcının mı yarattığı, bu noktada biraz çelişkilerim var. Benim bu noktadan başlamam gerekiyor aslında. Belki burayı çözersem devamı gelebilir."

Atalay Bey (ateist) ise, yaratıcı olmadığı için kendisini şüpheye düşürecek bir durumun da olmadığını vurguluyor: "Şüpheye düşmem için önce varlığına inanmam lazım."

\section{Deistlerin Dünyanın Yaratılması Hakkındaki Görüşleri}

Deist deneklere, bir yaratııının varlığına inandıkları halde dünyaya müdahalede bulunmadığını söylemeleri ve vahyi inkâr etmeleri sebebiyle, yaratııının dünyayı meydana getirmesindeki amacın ne olduğu sorulmuştur. Çalışmamızda yer alan 10 deist deneğin konuya ilişkin görüşleri aşağıda yer almaktadır.

Tablo 23: Yaratıcının Dünyayı Meydana Getirme Amacı

\begin{tabular}{|l|l|l|}
\hline Yaratıcının amacı & Kişi sayısı & Yüzde \% \\
\hline Amaçsız ve gereksiz & 5 & 50 \\
\hline Düzen oluşturmak için & 2 & 20 \\
\hline Net bir fikrim yok & 3 & 30 \\
\hline Toplam & $\mathbf{1 0}$ & $\mathbf{1 0 0 , 0}$ \\
\hline
\end{tabular}


Soruya cevap veren deneklerin yarısı (\%50) yaratııının dünyayı ve insanları yaratmada bir amacının olmadığını söylemiştir. \%20'si dünyada bir düzen oluşturmak istediği için insanları yarattığını belirtirken \%30’u konuyla ilgili net bir fikrinin olmadığını ifade etmiştir.

Sinem Hanım (deist), Tanrı'nın dünyayı ve insanları gereksiz yarattığını söylüyor:

Aslında herhangi bir mantıkla bunu gerçekleştirdiğini düşünmüyorum... İnsanlığın aslında kendi kendini evrimle gerçekleştirdiğini de düşünüyorum bazen.

\section{Evrim teorisine inanıyor musunuz?}

Bazı noktalarda evet, ama bazı noktalarda hayır diyebilirim. Allah'ın herhangi bir amacının olabileceğini düşünmüyorum. Allah bir amaç doğrultusunda insanları yaratıp "Hadi gidin dünyaya, bir bakayım ben sizin davranışlarınıza." Çünkü her şeyi bilen bir Allah, insanları sınava tabi tutmaz, gereksiz yarattı bence.

Hamdi Bey (deist), Tanrı́nın bir amacı bulunmadığını söylerken bazı noktalarda emin olmadığını belirtiyor:

Ben yaratııının dünyayı yaratma amacı olduğunu düşünmemekteyim. Daha çok şu kanaatteyim. Bir madde oluştu, bir anti madde oluştu, bunlar on binlere, trilyonlara çıktıktan sonra bu şekilde evren meydana geldi ve patlama oluştu. Bu düzen kendiliğinden oluşmadı. Fakat bu düzeni oluştururken bizimle bir şey yapmak istediğinden emin değilim. Bizimle alakası olduğunu bile düşünmüyorum. Bu da "ilki nasıl ortaya çıktı?" sorusunu getiriyor. Bir fikrim yok, kimse de açıklayamadı. Maymunlardan geldiğimizi de düşünmüyorum. Daha mantıklı bir sebebi olması lazım.

Seda Hanım (deist) ise, "Evrende artık düzeni olan bir yer olmasını gerektiğini düşünmüş. Bu düzeni de insanların oluşturacağına karar vermiştir diye düşünüyorum." şeklinde düşüncesini belirtiyor.

Burcu Hanım, deizmle ilgili kafasına en çok takılan konunun bu olduğunu dile getiriyor:

Zaten deizmin netleyemediğim kısmı burası. Buna net bir cevap veremeyeceğim. Bir yaratıcı var, dünyayı meydana getirmesindeki amaç ne? Yaratmış ve bırakmış diyebilirim. Müdahale yok buna, benim hayatıma müdahale yok, kader yok. Bu noktada yazıımış çizilmiş ve ben bunu yaşıyorum diye bir şey yok. Tercihler var, insanların tercihleri, hayat şekilleri var, kelebek etkisi diye bir şey var, doğaçlama gelişen bir şey.

Dilan Hanım (deist), Tanrı'nın dünyayı meydana getirmesi konusunda çok kafa yorduğunu fakat buna net bir cevap bulamadığını aktarıyor:

Bu konu hakkında çok tartıştık biz, gerçekten şöyle bir düzen de olabilir, bizim bilmediğimiz bir öte dünya da söz konusu olabilir. İnancım netleşmiş bir durumda değil şu an. İslam'da nefis terbiyesi diyorlar bu inanca. Bir şeylerin sorgusu, suali olabilir yaşadığımız dünyada. Hatta şöyle bir şey düşündük en son, Tanrı belki kendini de somutlaştırmak istedi, biz öte dünyada soyut varlıklarken bu dünyada belki somutlarız, belki Tanrı'nın kusurlarıyız ve Tanrı onları izliyor, her şey olabilir. Net bir düşüncem yok. Bir amacı olabilir, belki de hiçbir amacı yok, tesadüf eseri de olabilir.

Uğur Bey (deist) de konuyu net olarak bilmediğini ifade ediyor: "Dünyayı meydana getirmesindeki amacının kendisine tapılması için olduğunu düşünmüyorum sadece. Bu konuda fazla filgi sahibi değilim." 


\section{Sonuç}

Sosyometrinin sosyal olayları öldürmeden, canlı halde ölçüye vurma prensibine göre, Ateist ve Deistlerin Din Algısı başlı̆ı altında 15'i ateist (13 erkek, 2 kadın), 10'u deist (3 erkek, 7 kadın) toplam 25 gönüllü denekle gerçekleştirdiğimiz araştırmadan elde ettiğimiz veriler şu şekilde özetlenebilir:

Deneklerin \%88'i büyükşehir ve şehirlerde yetişmiştir. \%40'ı yarı demokrat ya da ilgisiz bir aile ortamında büyüdüğünü belirtmiş, \%12'sinin ebeveyni boşanmıştır. Annelerin $\% 36$ 'sı, babaların $\% 28^{\prime}$ i üniversite mezunudur.

Ebveynler arasında 1 ateist, 1 de deist baba bulunmaktadır. Deneklerin \%56'sı İslam dini hakkında yeterli bilgiye sahip olduğunu söylemiştir. Ortaya çıkan sonuçlara göre, ailesi tarafından dinî anlamda bilgilendirilmeyen birey, bu eksiğini daha sonraki süreçte başka bir şekilde giderememektedir. Deneklerin \%48'i dinî bilgilerini Kur'an kursundan elde ettiğini ifade etmiştir. Ancak Kur'an kursu tecrübesi olan deneklerin bir kısmı buradaki eğitimin kendilerini sıktığından bahsetmiştir. Bu da pedagojik eğitimle bağlantılı olarak dinden soğutulma ve din ile korkutulma kavramlarını akla getirmektedir.

Deneklerin yalnızca \%24'ü daha önce mensup olduğu i̇slam dini ile arasında çok sıkı bir bağ olduğunu beyan etmiştir. \%76'sı ise İslam dini ile herhangi bir bağının olmadığını (\%44) ya da çok zayıf (\%32) bir bağ bulunduğunu dile getirmiştir. Dualara cevap alamama, mucizeleri akıl yoluyla çözememe, dinin sömürülmesi gibi nedenler de onları dinden soğutan/uzaklaştıran diğer etkenler olarak zikredilmiştir.

Araştırmamızda yer alan deneklerin hiçbiri daha önce herhangi bir cemaate mensup olmamıştır. i̇badetleri yerine getirme konusunda kısmen annelerin müdahil olduğunu, babaların ise bu konuya çok karışmadığını görmekteyiz. Kendi ibadetlerini yerine getirme konusunda da annelerin babalara göre daha ön planda olduğu ortaya çıkmıştır.

Daha önceki süreçte hiçbir şekilde ibadet gerçekleştirmeyen deneklerin oranı (\%32) azımsanmayacak düzeydedir. Geri kalanlar ise (\%64), ya arasıra ibadet ettiğini veya bazı ibadetleri gerçekleştirdiğini ya da ibadetleri belli bir dönem için yerine getirdiğini belirtmiştir. Sürekli ibadet eden denek sayısı yalnızca 1'dir.

Deneklerin \%36'sı ateist veya deist olmadan önce ateizm ya da deizm hakkında olumlu bir düşünceye sahiptir. \%32'si sosyalist düşünceyi benimsemiştir. \%64'ü Kur'an'ı, Müslümanları veya yaratııışı sorgulaması sonunda ateist veya deist olduğunu vurgulamıştır.

Araştırmada yer alan deneklerin \%32'si travmatik bir olay tecrübesine sahiptir. Buna göre, ciddi bir trafik kazası, yakın akrabaların peşpeşe ölümü, kendisi yüzünden intihara kalkışan birinin varlığı, şiddetli ailevî sorunlar, anne-baba boşanması, trafik kazasında arkadaş kaybı, annesi çalışığı için ondan uzak büyüme, genç yaşta babasız kalma gibi farklı travmatik olaylar sözkonusudur.

Büyük çoğunluğun (\%72) ailesinde ya da çevresinde ateist veya deist bir tanıdık vardır. Deneklerin \%44'ü ateist veya deist olurken onlardan etkilendiğini söylemiştir. Deneklerin $\% 56$ 'sı ateist/deist olduktan sonra başka bireylerin de kendilerinden etkilenerek ateizm veya deizmi benimsediğini ifade etmiştir.

Ateist ve deistlerin yarıdan fazlasının (\%64) kafası karışıktır. Ateistler arasında Tanrı'nın var olabileceği, deistler arasında Tanrı'nın yeryüzüne müdahil olup olmaması ve her iki grup içinde ölüm sonrası hayat zihinleri kurcalayan konuların başında gelmektedir.

Deneklerin tamamına yakını (\%92) ateist veya deist olduktan sonra İslam dini hakkında eleştiride bulunmaya devam etmiştir. Eleştiriler daha çok bazı Kur'an ayetlerinin yaratıı tarafından söylenmiş olamayacağı, kadın hakları konusu ve zinanın artık bugün yasak olmaması gerektiği gibi konular etrafında şekillenmiştir. 
Deneklerin \%36'sı (3 ateist, 6 deist), tekrar bir dine inanabileceğini belirtmektedir. Bu rakam bile başı başına deneklerin, aslında yaratııının ve dinin olmadığını düşünmelerinden değil, dinden soğutulmasından, uzaklaştııımasından ve din ile korkutulmasından kaynaklanıyor olabilir. Soruya "Allah bilir..." şeklinde cevap veren ateistin, dil sürçmesi bir yana bırakılırsa, peşinden sürüklendiği ideolojiyle entellektüel bir bağının olmadığı söylenebilir.

Ölüm sonrasına gelince burada deneklerin tamamı ateist veya deist farketmeden birbirine yakın cevaplar vermiştir. Deneklerin \%60'। (9 ateist, 6 deist) ölüm sonrası hayata inanmazken; \%24'ü (5 ateist, 1 deist) fikrinin olmadığını, \%8'i (1 ateist, 1 deist) reenkarnasyona inandığııı ifade etmiştir. \%8'lik ( 2 deist) bir grup ise "diğer" seçeneği içinde yer almış, bu iki denekten biri tamamen yokluğun olmadığını, biri de dünyada yaşamın devam edeceğini dile getirmiştir.

Araştırmamızdan ortaya çıkan sonuç; ateist ve deistlerin düşünceleri arasında tek fark, sanki Tanrı́ya inanıp inanmamaları konusuyla sınırlı gibi gözükmektedir. Ateistler Tanrı́nın varlığını kabul etmezken, deistler Tanrı'nın varlığına inanmaktadır. Deneklerin sahip olduğu inancın duygusal ihtiyaçlarla şekillendiği, entellektüel birer ateist veya deist yerine dinden soğutulmuş, uzaklaştırılmış, dinle korkutulmuş bireyler oldukları ön plana çıkmaktadır.

Bu bağlamda, vahiy dahil din için önemli pekçok esasın bir kenara itilmesi, ateistlerin düşüncelerini desteklemiştir. Deistlerin semavî dinlere yönelttiği eleştirileri, ateistler de deizme yöneltmiştir. Vahye, mucizeye, ahiret hayatına yer vermeyen, Tanrı'yı evrene müdahale ettirmeyen bir anlayış (deizm), ateizme giden yolun yarıdan çoğunun katedilmesine imkân tanımış olmaktadır. ${ }^{35}$

\section{Kaynakça / References}

Aydın, M. (1996). Din Felsefesi. Ankara: Selçuk Yayınları.

Bayer, A. (2006). Sosyolojik Perspektiften Sekülerleşme ve Din ilişkisine Yeniden Bakış. Kahramanmaraş Sütçü İmam Üniversitesi, Sosyal Bilimler Enstitüsü, Yayınlanmamış Yüksek Lisans Tezi.

Cevizci, A. (1999). Felsefe Sözlügü. İstanbul: Paradigma Yayınları.

Coşkun, i. (2010). Ateizm ve İslam: Kelami Açıdan Modern Çağ Ateizminin Eleştirisi. Ankara: Ankara Okulu Yayınları.

Dorman, E. (2009). Deizm ve Eleştirisi: Tarihsel ve Teolojik Bir Yaklaşım. Marmara Üniversitesi, Sosyal Bilimler Enstitüsü, Yayımlanmamış Doktora Tezi.

\footnotetext{
${ }^{35}$ Aydın, ss. 176-177.
} 
Dorman, E. (2017). Modern Çağda Deizmin Popülerleşmesi ve Sebepleri. Diyanet Aylık Dergi, 2017 (320), ss. 14-18.

Erdem, H. (1994). Deizm. TDV Islam Ansiklopedisi, C: 9, İstanbul: TDV Yayınları.

Ergezen, E. (2004). Günümüz Ateistlerinde Hayatı Anlamlandırma. Ankara Üniversitesi, Sosyal Bilimler Enstitüsü, Yayınlanmamış Yüksek Lisans Tezi.

Geçtan, E. (1992). Psikodinamik Psikiyatri ve Normal Dışı Davranışlar. İstanbul: Remzi Kitabevi.

Giddens, A. (2008). Sosyoloji. (Yayıma Hazırlayan: Cemal Güzel), İstanbul: Kırmızı Yayınları.

Kandemir, Y.; Zavalsız, H. \& Şimşek, Ü. (2010). Ayet ve Hadislerle Açıklamalı Kur'an-ı Kerim Meali I-II. İstanbul: IFAV Yayınları.

Köktaş, M. (2017). Aydınlanma, Hristiyanlık ve Deizm, Anadolu Üniversitesi Sosyal Bilimler Dergisi, 17 (1), ss. $143-157$.

Kulat, M. A. (2017). Türkiye'de Toplumun Dine ve Dini Değerlere Bakışı, MAK Danışmanlık, 12-18 Haziran 2017.

Kurt, A. (2015). Din Sosyolojisi. İstanbul: Sentez Yayınları.

Martin, M. (2013). Ateizm ve Din. (Çeviren: Yaşar Ünal), Kelam Araştırmaları, 11 (1), ss. 575-590.

Ögcem, E. (2013). Ateizmden Deizme Antony Flew. Marmara Üniversitesi, Sosyal Bilimler Enstitüsü, Yayınlanmamış Doktora Tezi.

Russel, B. (1972). Bilim ve Din. Varlık Dergisi, 780.

Telimen, M. (2012). Alevi Gençliği ve Ateizm (İstanbul ve Tunceli Örneği). Süleyman Demirel Üniversitesi, Sosyal Bilimler Enstitüsü, Yayınlanmamış Yüksek Lisans Tezi.

Taylan, N. (2000). Düşünce Tarihinde Tanrı Sorunu. İstanbul: Şehir Yayınları.

Topaloğlu, A. (2001). Teizm ya da Ateizm: Tanrıtanımazlığın Felsefi Boyutları. İstanbul: Furkan Yayınları.

Vergote, A. (1978). Çocuklukta Din. (Çev: Erdoğan Fırat), Ankara Üniversitesi Ilahiyat Fakültesi Dergisi, 22 (1), ss. 315-329.

Wood, A. W. (2011). Kant'ın Deizmi. (Çeviri: Necmettin Tan), Ankara Üniversitesi Ilahiyat Fakültesi Dergisi, $52(1)$, ss. 327-347.

Zavalsız, Y. S. (2012). Din Değiştirmenin Psiko-Sosyal Kodları. Çukurova Üniversitesi Ilahiyat Fakültesi Dergisi, Din Psikolojisi Özel Sayısı, 12 (2), ss. 185-200.

Zavalsız, Y. S. (2017). Türkiye'de Hıristiyan Olan Müslümanlar: Psiko-Sosyolojik Bir Araştırma (1990-2010). Ankara: Berikan Yayınları. 